
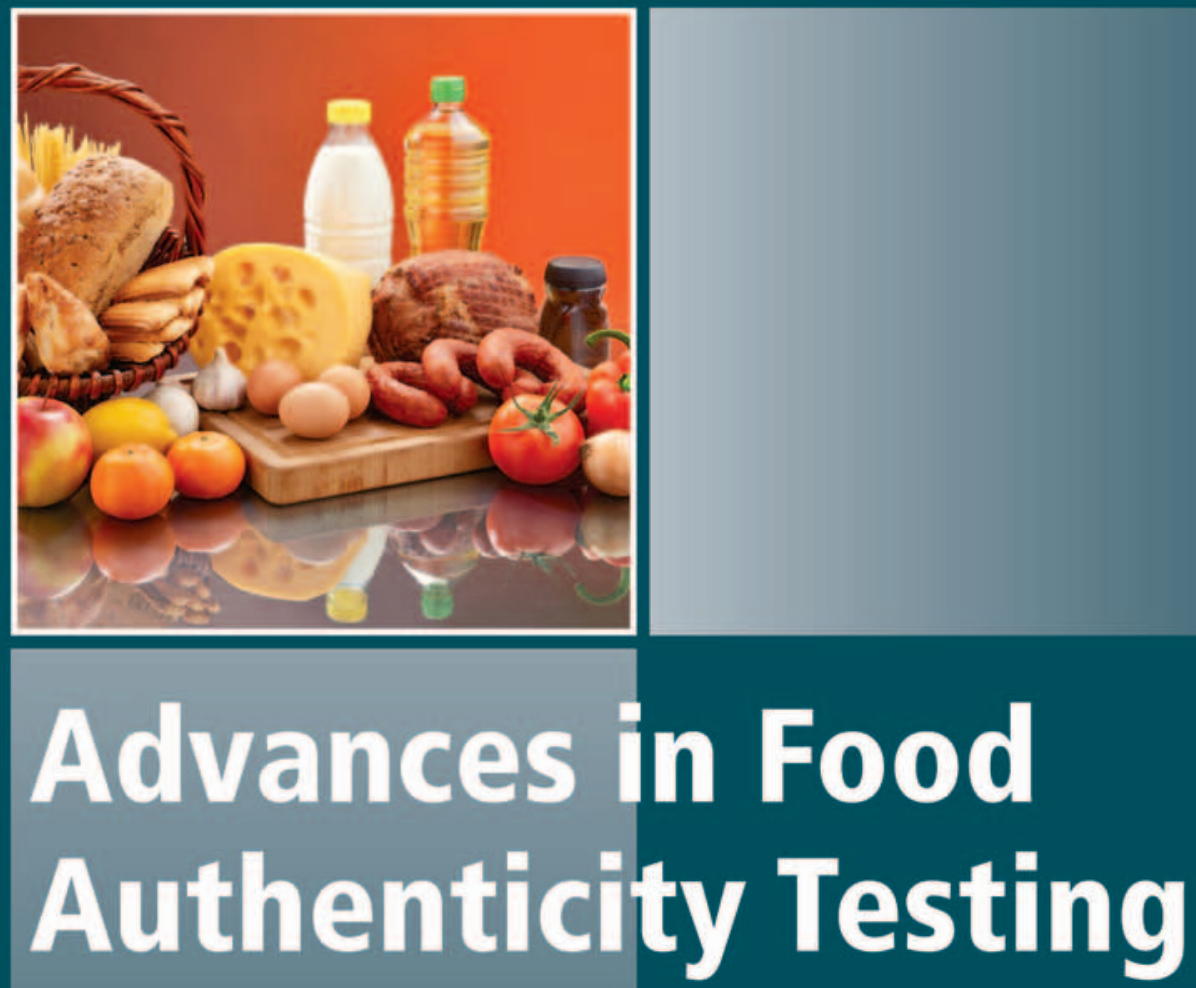

Advances in Food

Authenticity Testing

Improving Quality Throughout the

Food Chain

Edited by Gerard Downey 
Advances in Food Authenticity Testing 
This page intentionally left blank 


\section{Advances in Food Authenticity Testing}

Edited by

Gerard Downey

Teagasc Food Research Centre Dublin, Republic of Ireland

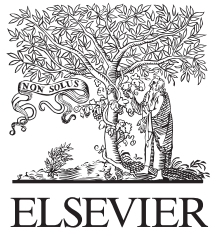

AMSTERDAM • BOSTON • CAMBRIDGE • HEIDELBERG LONDON • NEW YORK • OXFORD • PARIS • SAN DIEGO SAN FRANCISCO • SINGAPORE - SYDNEY • TOKYO Woodhead Publishing is an imprint of Elsevier 
Woodhead Publishing is an imprint of Elsevier

The Officers' Mess Business Centre, Royston Road, Duxford, CB22 4QH, United Kingdom 50 Hampshire Street, 5th Floor, Cambridge, MA 02139, United States

The Boulevard, Langford Lane, Kidlington, OX5 1GB, United Kingdom

Copyright (C) 2016 Elsevier Ltd. All rights reserved.

No part of this publication may be reproduced or transmitted in any form or by any means, electronic or mechanical, including photocopying, recording, or any information storage and retrieval system, without permission in writing from the publisher. Details on how to seek permission, further information about the Publisher's permissions policies and our arrangements with organizations such as the Copyright Clearance Center and the Copyright Licensing Agency, can be found at our website: www.elsevier.com/permissions.

This book and the individual contributions contained in it are protected under copyright by the Publisher (other than as may be noted herein).

\section{Notices}

Knowledge and best practice in this field are constantly changing. As new research and experience broaden our understanding, changes in research methods, professional practices, or medical treatment may become necessary.

Practitioners and researchers must always rely on their own experience and knowledge in evaluating and using any information, methods, compounds, or experiments described herein. In using such information or methods they should be mindful of their own safety and the safety of others, including parties for whom they have a professional responsibility.

To the fullest extent of the law, neither the Publisher nor the authors, contributors, or editors, assume any liability for any injury and/or damage to persons or property as a matter of products liability, negligence or otherwise, or from any use or operation of any methods, products, instructions, or ideas contained in the material herein.

\section{Library of Congress Cataloging-in-Publication Data}

A catalog record for this book is available from the Library of Congress

\section{British Library Cataloguing-in-Publication Data}

A catalogue record for this book is available from the British Library

ISBN: 978-0-08-100220-9

For information on all Woodhead Publishing publications visit our website at https://www.elsevier.com/

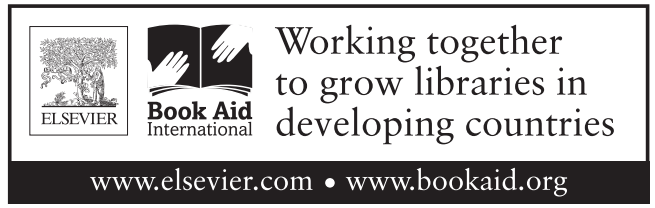

\section{Publisher: Nikki Levy}

Acquisition Editor: Rob Sykes

Editorial Project Manager: Karen Miller

Production Project Manager: Debbie Clark

Designer: Greg Harris

Typeset by TNQ Books and Journals 


\section{Contents}

List of Contributors $\quad$ xiii

1 Introduction $\quad 1$

G. Downey
References

Part One Advances in Methods for Food Authenticity Testing 5

2 Advances in DNA Fingerprinting for Food Authenticity Testing 7

W.F. Nader, T. Brendel and R. Schubbert

2.1 Introduction $\quad 7$

2.2 Scientific Background of DNA Fingerprinting and Its Applications 9

2.3 The Methodology of DNA Fingerprinting $\quad \mathbf{1 1}$

2.4 DNA Fingerprinting for Authenticity Testing of Rice Varieties 22

2.5 Meat Traceability $\quad 27$

2.6 Future Trends $\quad \mathbf{2 8}$

References $\quad 29$

3 Advances in Ultraviolet and Visible Light Spectroscopy for Food Authenticity Testing

M.J. Martelo-Vidal and M. Vázquez

3.1 Introduction $\quad \mathbf{3 5}$

3.2 Fundamentals of Ultraviolet and Visible Light Spectroscopy in Food Analysis

3.3 Application of UV-VIS Spectroscopy for Authentication of Foodstuffs

3.4 Suitable Foodstuffs for Testing Using Ultraviolet and Visible Light Spectroscopy Analysis

3.5 Case Study: Wine Authentication $\quad 59$

$\begin{array}{ll}\text { References } & 63\end{array}$

4 Advances in Infrared Spectroscopy for Food Authenticity Testing $\quad 71$

L.E. Rodriguez-Saona, M.M. Giusti and M. Shotts

4.1 Introduction $\quad \mathbf{7 1}$

4.2 Vibrational Spectroscopy as a Screening Method 72 
4.3 Chemometrics in Vibrational Spectroscopy

4.4 Screening Capabilities of Vibrational Spectroscopy to Detect Adulteration in Foods

4.5 The Future of Vibrational Spectroscopy in Food Authentication:

Portable and Handheld Technology

102

Sources of Further Information

107

References

107

5 Advances in Fluorescence Emission Spectroscopy for Food Authenticity Testing

A. Dankowska

5.1 Introduction

5.2 What Adulterations Can Fluorescence Emission Spectroscopy Be Used to Detect?

5.3 Applications of Fluorescence Emission Spectroscopy for Food Authentication - Examples

5.4 Future Trends

References

6 Advances in Nuclear Magnetic Resonance Spectroscopy for Food Authenticity Testing

A.P. Sobolev, S. Circi and L. Mannina

6.1 Introduction

6.2 Nuclear Magnetic Resonance Methodologies in Food Analysis

6.3 Sample Preparation for Nuclear Magnetic Resonance Analysis

6.4 Spectral Assignment and Quantitative Analysis

6.5 Adulterations Detected by Nuclear Magnetic Resonance Spectroscopy

6.6 Future Trends

References

7 Advances in Mass Spectrometry for Food Authenticity Testing: An Omics Perspective

T. Cajka, M.R. Showalter, K. Riddellova and O. Fiehn

7.1 Introduction

7.2 Process of Using Mass Spectrometry in the Analysis of Food

7.3 Mass Spectrometry-Based Approaches for Food Authenticity

Testing and Adulteration Detection

7.4 Future Trends

Acknowledgments

195

References 
8 Advances in Electronic Noses and Tongues for Food Authenticity Testing

M. Śliwińska, P. Wiśniewska, T. Dymerski, W. Wardencki and

J. Namieśnik

8.1 Introduction

8.2 Electronic Nose

8.3 Electronic Tongue $\quad \mathbf{2 0 5}$

8.4 Application of Electronic Nose and Tongue in Food Authenticity Studies

8.5 Conclusions

References

9 Advances in Isotopic Analysis for Food Authenticity Testing

K.H. Laursen, L. Bontempo, F. Camin and A. Roßmann

9.1 Introduction

9.2 Measurements, Instrumentation, and Applications

9.3 Case Studies

9.4 Conclusion and Future Trends

Sources of Further Information $\quad 246$

Abbreviations

Acknowledgments

References

10 Advances in Chromatographic Techniques for Food Authenticity Testing

C. Fanali, L. Dugo and L. Mondello

10.1 Introduction

10.2 Process of Using Chromatographic Techniques in the Analysis of Food

10.3 Adulterations Which Can Be Detected by Using Chromatographic Techniques

10.4 Foodstuffs Suitable for Testing Using Chromatographic Techniques

10.5 Case Studies

10.6 Future Trends

Sources of Further Information

11 Advances in Polymerase Chain Reaction Technologies for Food Authenticity Testing

E. Maestri and N. Marmiroli

11.1 Introduction

11.2 Process of Using PCR Technologies in the Analysis of Food

11.3 Application of PCR Technologies to Detect Adulteration

11.4 Case Studies 
$\begin{array}{lll}11.5 & \text { Future Trends } & \mathbf{3 0 1}\end{array}$

Sources of Further Information and Conclusions $\quad \mathbf{3 0 3}$

Acknowledgments $\quad 304$

References $\quad 304$

12 Advances in Differential Scanning Calorimetry for Food Authenticity Testing

T. Nur Azira and I. Amin

12.1 Introduction $\mathbf{3 1 1}$

12.2 Uses of Differential Scanning Calorimetry in the Analysis of Foods $\mathbf{3 1 2}$

12.3 Uses of Differential Scanning Calorimetry in Food Authenticity Testing

12.4 Conclusions and Future Perspectives 329

Sources of Further Information 329

References $\quad 330$

Part Two Advances in Authenticity Testing 337

13 Advances in Authenticity Testing of Geographical Origin of Food Products

A.M. Pustjens, M. Muilwijk, Y. Weesepoel and S.M. van Ruth

13.1 Introduction 339

13.2 Techniques for Analyzing Isotopes 340

13.3 Techniques for Analyzing Elements 343

13.4 Separation Techniques for Compositional Analysis 344

13.5 (Semi-)Nondestructive Techniques 349

$\begin{array}{lll}13.6 & \text { Other Techniques } & \mathbf{3 5 7}\end{array}$

13.7 Conclusions $\quad 358$

List of Abbreviations of Analytical Equipment $\quad 358$

List of Abbreviations of (Multivariate) Statistical Analysis 359

References $\quad 360$

14 Advances in Authenticity Testing for Meat Speciation 369

J. Amaral, L. Meira, M.B.P.P. Oliveira and I. Mafra

$\begin{array}{lll} & \text { Introduction } & \mathbf{3 6 9}\end{array}$

$\begin{array}{lll}14.2 & \text { Protein-Based Methods } & 371\end{array}$

14.3 DNA-Based Methods 376

14.4 Spectroscopic Methods

14.5 Final Remarks $\quad \mathbf{4 0 2}$

References $\quad 403$

15 Advances in Authenticity Testing for Fish Speciation 415

M. Espiñeira and F. Lago

15.1 Introduction $\quad \mathbf{4 1 5}$

15.2 Methods Used in Fish Speciation $4 \mathbf{4 1 7}$ 
15.3 Case Studies

15.4 Future Trends

432

Sources of Further Information

434

References

16 Authentication of Cereals and Cereal Products

D. Cozzolino

16.1 Introduction

16.2 Application of NIR and MIR Spectroscopy to Cereal Grain Authentication

16.3 Concluding Remarks

References

\section{Part Three Advances in Authenticity Testing} for Food Adulteration

17 Advances in Testing for Adulteration and Authenticity of Dairy Products

G.A. Abernethy, J.G. Bendall and S.E. Holroyd

17.1 Introduction

17.2 Types of Dairy Product Adulteration and Nonauthenticity

17.3 Chemical Methods to Combat Nonauthenticity

17.4 Spectroscopic Methods to Determine Adulteration $\mathbf{4 7 6}$

17.5 Future Developments $\quad \mathbf{4 8 0}$

Acknowledgment $\quad 481$

$\begin{array}{ll}\text { References } & 481\end{array}$

18 Advances in the Identification of Adulterated Cereals and Cereal Products

S.R. Delwiche

18.1 Introduction

18.2 Legislation $\mathbf{4 9 3}$

18.3 Methodology for Phenotyping and Geography 496

18.4 Melamine $\quad \mathbf{5 0 0}$

18.5 Durum $\quad \mathbf{5 0 3}$

18.6 Basmati $\quad \mathbf{5 0 5}$

18.7 Wheat Gluten as an Adulterant $\quad \mathbf{5 0 7}$

18.8 Application of Using NIR Technology for Mixtures of Nonwaxy (Conventional) and Waxy Wheat $\quad 509$

18.9 Conclusion $\quad \mathbf{5 1 1}$

Sources of Further Information $\quad \mathbf{5 1 2}$

References 
19 Advances in the Identification of Adulterated Vegetable Oils

$O$. Abbas and V. Baeten

19.1 Introduction

19.2 Authenticity Testing of Adulterated Vegetable Oils, Including Case Studies

19.3 Conclusions and Future Trends $\quad \mathbf{5 3 4}$ References $\quad \mathbf{5 3 5}$

20 Advances in the Identification of Genetically Modified Foods

M.-A. Fraiture, S. Broeders, P. Herman, I. Taverniers, M. De Loose,

D. Deforce and N.H. Roosens

20.1 Introduction

20.2 Processes Used for Identification of Genetically Modified Foods

20.3 Case Studies

20.4 Future Trends

552

Sources of Further Information

555

Acknowledgments

555

References

556

21 Advances in the Detection of the Adulteration of Alcoholic Beverages Including Unrecorded Alcohol

D.W. Lachenmeier

21.1 Introduction

21.2 Processes Used in the Detection of Alcoholic Beverage Adulteration

21.3 Case Studies

575

21.4 Future Trends

Sources of Further Information

References

22 Advances in Adulteration and Authenticity Testing of Herbs and Spices

B. Sasikumar, V.P. Swetha, V.A. Parvathy and T.E. Sheeja

22.1 Introduction

585

22.2 Uses of Spices and Herbs

22.3 Adulterants in Spices and Herbs

22.4 Techniques for Adulterant Detection

22.5 Future Perspectives and Conclusions

612

References

23 Tradition Meets High Tech for Authenticity Testing of Fruit Juices

P. Rinke

23.1 Introduction

23.2 Overview of Methods Applied in Standard Control 
23.3 Conventional Methods $\quad \mathbf{6 2 8}$

23.4 Overview of Modern Techniques $\quad \mathbf{6 3 8}$

23.5 Case Study Combining Different Methods $\quad \mathbf{6 5 3}$

23.6 Importance of Databases and Documentation $\quad \mathbf{6 5 5}$

23.7 Outlook $\quad \mathbf{6 5 6}$

Acknowledgments $\quad 658$

References $\quad 658$

24 Advances in Testing for Adulteration of Food Supplements $\quad 667$

S.H. El-Ahmady and M.L. Ashour

24.1 Introduction $\quad \mathbf{6 6 8}$

24.2 Adulteration of Food Supplements $\quad \mathbf{6 7 3}$

24.3 Methods of Adulterant Detection $\quad \mathbf{6 8 3}$

24.4 Global Agencies and Authorities Responsible for
Drug and Food Supplement Safety

24.5 Future Perspectives $\quad \mathbf{6 9 1}$

References

25 Chemometrics for Food Authenticity Applications 701

$P$. Oliveri and R. Simonetti

25.1 Introduction $\quad \mathbf{7 0 2}$

$\begin{array}{ll}25.2 & \text { Multivariate Data Analysis } \\ \end{array}$

Acknowledgment $\quad \mathbf{7 2 6}$

References $\quad \mathbf{7 2 6}$

26 Advances in Testing for Adulteration in Honey 729

F. Ulberth

26.1 Introduction $\quad \mathbf{7 2 9}$

26.2 Processes Used in Identification of Adulteration in Honey 732

26.3 Outlook $\quad \mathbf{7 4 5}$

References $\quad 745$

$\begin{array}{ll}\text { Index } & 755\end{array}$ 
This page intentionally left blank 


\section{List of Contributors}

O. Abbas Walloon Agricultural Research Centre (CRA-W), Gembloux, Belgium G.A. Abernethy Fonterra Research \& Development Centre, Palmerston North, New Zealand

J. Amaral University of Porto, Porto, Portugal

I. Amin Universiti Putra Malaysia, Serdang, Selangor, Malaysia

M.L. Ashour Ain Shams University, Cairo, Egypt

V. Baeten Walloon Agricultural Research Centre (CRA-W), Gembloux, Belgium

J.G. Bendall Fonterra Research \& Development Centre, Palmerston North, New Zealand

L. Bontempo Research and Innovation Centre, Trentino, Italy

T. Brendel Eurofins Medigenomix GmbH, Ebersberg, Germany

S. Broeders Scientific Institute of Public Health, Brussels, Belgium

T. Cajka University of California, Davis, Davis, CA, United States

F. Camin Research and Innovation Centre, Trentino, Italy

S. Circi University of Rome, Rome, Italy

D. Cozzolino Central Queensland University, Rockhampton, Queensland, Australia

A. Dankowska Poznań University of Economics and Business, Poznań, Poland

D. Deforce Ghent University, Ghent, Belgium

M. De Loose Institute for Agricultural and Fisheries Research (ILVO), Merelbeke, Belgium

S.R. Delwiche USDA, Agricultural Research Service, Beltsville, MD, United States

G. Downey Teagasc Food Research Centre, Dublin, Republic of Ireland

L. Dugo Università Campus Bio-Medico of Rome, Rome, Italy

T. Dymerski Gdansk University of Technology, Gdańsk, Poland 
S.H. El-Ahmady Ain Shams University, Cairo, Egypt

M. Espiñeira ANFACO-CECOPESCA, Vigo, Spain

C. Fanali Università Campus Bio-Medico of Rome, Rome, Italy

O. Fiehn University of California, Davis, Davis, CA, United States

M.-A. Fraiture Scientific Institute of Public Health, Brussels, Belgium

M.M. Giusti College of Food Agriculture and Environmental Sciences, The Ohio State University, OH, United States

P. Herman Scientific Institute of Public Health, Brussels, Belgium

S.E. Holroyd Fonterra Research \& Development Centre, Palmerston North, New Zealand

D.W. Lachenmeier Chemisches und Veterinäruntersuchungsamt (CVUA) Karlsruhe, Karlsruhe, Germany

F. Lago ANFACO-CECOPESCA, Vigo, Spain

K.H. Laursen University of Copenhagen, Copenhagen, Denmark

E. Maestri University of Parma, Parma, Italy

I. Mafra University of Porto, Porto, Portugal

L. Mannina Sapienza University of Rome, Rome, Italy

N. Marmiroli University of Parma, Parma, Italy

M.J. Martelo-Vidal University of Santiago de Compostela, Lugo, Spain

L. Meira University of Porto, Porto, Portugal

L. Mondello Università Campus Bio-Medico of Rome, Rome, Italy

M. Muilwijk Wageningen University and Research Centre, Wageningen, The Netherlands

W.F. Nader Eurofins Global Control GmbH, Hamburg, Germany

J. Namieśnik Gdansk University of Technology, Gdańsk, Poland

T. Nur Azira International Islamic University Malaysia, Kuala Lumpur, Malaysia M.B.P.P. Oliveira University of Porto, Porto, Portugal

P. Oliveri University of Genova, Genova, Italy

V.A. Parvathy ICAR-Indian Institute of Spices Research, Kozhikode, Kerala, India A.M. Pustjens Wageningen University and Research Centre, Wageningen, The Netherlands

K. Riddellova ALS Czech Republic s.r.o., Prague, Czech Republic 
P. Rinke SGF International E.V., Nieder-Olm, Germany

L.E. Rodriguez-Saona College of Food Agriculture and Environmental Sciences, The Ohio State University, OH, United States

N.H. Roosens Scientific Institute of Public Health, Brussels, Belgium

A. Roßmann Isolab GmbH Laboratory for Stable Isotopes, Schweitenkirchen, Germany

B. Sasikumar ICAR-Indian Institute of Spices Research, Kozhikode, Kerala, India

R. Schubbert Eurofins Medigenomix GmbH, Ebersberg, Germany

T.E. Sheeja ICAR-Indian Institute of Spices Research, Kozhikode, Kerala, India

M. Shotts College of Food Agriculture and Environmental Sciences, The Ohio State University, $\mathrm{OH}$, United States

M.R. Showalter University of California, Davis, Davis, CA, United States

R. Simonetti University of Genova, Genova, Italy

M. Śliwińska Gdansk University of Technology, Gdańsk, Poland

A.P. Sobolev National Research Council, Rome, Italy

V.P. Swetha ICAR-Indian Institute of Spices Research, Kozhikode, Kerala, India

I. Taverniers Institute for Agricultural and Fisheries Research (ILVO), Merelbeke, Belgium

F. Ulberth European Commission, Geel, Belgium

S.M. van Ruth Wageningen University and Research Centre, Wageningen, The Netherlands

M. Vázquez University of Santiago de Compostela, Lugo, Spain

W. Wardencki Gdansk University of Technology, Gdańsk, Poland

Y. Weesepoel Wageningen University and Research Centre, Wageningen, The Netherlands

P. Wiśniewska Gdansk University of Technology, Gdańsk, Poland 
This page intentionally left blank 


\title{
Advances in Authenticity Testing for Meat Speciation
}

\author{
J. Amaral, L. Meira, M.B.P.P. Oliveira, I. Mafra \\ University of Porto, Porto, Portugal
}

\section{Chapter Outline}

\subsection{Introduction 369}

14.2 Protein-Based Methods 371

14.2.1 Electrophoretic Techniques 371

14.2.2 Immunochemical Techniques 372

14.2.3 Chromatographic and Mass Spectrometry Techniques 374

\subsection{DNA-Based Methods 376}

14.3.1 PCR-RFLP 379

14.3.2 Species-Specific PCR 383

14.3.3 PCR-Sequencing 383

14.3.4 DNA Barcoding 390

14.3.5 Real-Time PCR 391

14.5.6 Next-Generation Sequencing 392

14.3.7 Biosensors 398

14.4 Spectroscopic Methods 399

14.5 Final Remarks 402

References 403

\subsection{Introduction}

Nowadays, and particularly after the horse meat scandal in Europe, consumers are increasingly aware of the problem of food adulteration and consequently demand clear and reliable information about the composition of foods they are buying and eating. Meat, a highly appreciated premium source of protein, is among the foods most prone to suffer adulteration for economic gain. According to EU legislation laying down the general principles and requirements of food law (European Commission, 2002) and EU labeling regulations (European Commission, 2001), meat products should be accurately labeled regarding their species content, with food adulteration and misleading information being considered illegal. However, because of its high demand and value, frauds in the meat industry and retail markets have become a widespread problem, especially in ground and comminuted meat products. Adulteration in the meat sector encompasses many issues, including the substitution of high-quality muscle proteins 
by other, lower-value meat species or by vegetable proteins, the addition of undeclared ingredients such as constituents of animal origin (eg, blood plasma, offal), the addition of nonmeat components such as water and additives, mislabeling regarding the quantity of meat ingredients, the geographical origin of meats and/or the animal feeding regime, and undeclared processing methods in meat products, such as irradiation and thawed meat (Ballin, 2010; Montowska and Pospiech, 2011a). All these practices are of concern, either for economic reasons, as they lead to unfair competition among producers and deceive consumers, or for health reasons since traceability is compromised. Additionally, they restrict consumers' freedom of choice, in particular for those who choose to follow strict diets for religious motives since the consumption of certain species is not allowed in some religions. For example, pork and its derivatives (among other species) are strictly forbidden to Muslims and Jews who can only consume halal or kosher meat, respectively. For those consumers, the presence of certain animal species, which are undeclared on the product label, is perhaps of most concern.

Adulteration of meat and meat products because of species substitution is also of major importance in the case of traditional products and/or game meat (Montowska and Pospiech, 2012a; Costa et al., 2016a) since both types of products are frequently more expensive and perceived by consumers as being of superior quality. In the case of game meat, its consumption has been increasing in recent years, mainly because of its particular taste and flavor but also because it may be considered a healthier and less-fat meat, obtained from animals free of hormones and drugs such as antibiotics. However, game meat supply depends on animal availability and can sometimes be restricted to hunting seasons. This, together with its generally higher price, makes game meat and products thereof very prone to adulteration by fraudulent substitution of meat species (Amaral et al., 2014, 2015). Traditional foods, frequently considered as delicacies, are another type of product that is highly susceptible to meat species substitution. Among the regional and traditional products in the European Union labeled with the logos of protected designation of origin (PDO), protected geographical indication (PGI), or traditional specialty guaranteed (TSG), there are currently 146 registered products in the category of "Fresh meat and offal" and 155 in "Meat products (cooked, salted, smoked, etc.)." From those, several are produced from specific breeds as described in the specifications accompanying the application for registration. For example, the Portuguese meat products "Morcela de Estremoz e Borba" (PGI) and "Presunto de Barrancos" (PDO) are produced from pork meat exclusively from the Alentejana breed (Sus ibericus), and the lamb meat "Cordeiro Mirandês" refers exclusively to the Churra Galega Mirandesa breed. Many other examples, similar to these, from other countries could be mentioned. Since products holding PDO, PGI, or TSG logos generally command higher prices than other comparable meat products, they are susceptible targets for economic fraud through undeclared substitution of the specified meat by other meat from a similar breed.

Considering the relevance of species substitution in the subject of meat adulteration, this chapter intends to provide an updated overview, attempting to have a global world coverage on the most recent research studies regarding the development of methodologies for meat and meat product authenticity testing with respect to speciation and the applicability to the identification of meat species in commercial products. 


\subsection{Protein-Based Methods}

In each species, the genes (genome) predetermine the amino acid composition of the expressed proteins, their quantity, and rate of synthesis (Montowska and Pospiech, 2011a). Since the proteome of an organism is the result of the expression of its genome, the analysis of proteins has been frequently suggested for species identification purposes. As a result, different protein-based methodologies, including electrophoretic, chromatographic, and immunochemical techniques, have been proposed for meat and meat product authentication studies. However, when evaluating the suitability of these methods, it should be taken into account that protein composition can vary, not only among species, but also with many other factors, including tissue type, animal's age and sex, meat processing treatments, and storage period. Therefore the application of protein-based methods generally gives better results when applied to species identification in raw than in processed meat products. In this case the difficulties to overcome are related to the complexity and variability of foods, as well as the type of processing that can frequently induce protein denaturation or degradation.

\subsubsection{Electrophoretic Techniques}

Electrophoresis is a powerful technique based on the use of an electric field for the separation of proteins into distinctive patterns. It includes different electrokinetic separation techniques according to the principle used for protein separation, such as differences in electrophoretic mobility, isoelectric point, molecular size, or a combination of these. Electrophoresis can be conducted either on gel, such as the case of polyacrylamide gel electrophoresis (PAGE) and its modification using sodium dodecyl sulfate as a denaturing agent (SDS-PAGE), isoelectric focusing (IEF), and, more recently, two-dimensional electrophoresis (2-DE), or in small narrow capillaries, such as the case of capillary zone electrophoresis and capillary isoelectric focusing among others. Apart from being routinely used as a tool in different DNA-based methods and being very useful in proteomic studies performed by mass spectrometry (MS), electrophoretic methods per se have also been applied for meat species identification. There are only a few reports on meat authentication by protein gel electrophoresis, despite being considered a well-known and frequently used technique for species identification in raw fish and control of marine products (Montowska and Pospiech, 2007, 2012a; Etienne et al., 2000). The first studies used SDS-PAGE and IEF on polyacrylamide gel to identify meat cuts of different species (cow, sheep, lamb, goat, red deer, and rabbit) and obtained somewhat ambiguous results (Hofmann, 1985 referred in Montowska and Pospiech, 2007). Since several factors, other than the animal species, can affect the results achieved by SDS-PAGE, this technique frequently presents some constraints when applied for species authentication purposes, in particular regarding meat mixtures and processed meat products, because of its lack of reproducibility and low discriminating power. IEF has also been used for species identification in raw meat (Kaiser et al., 1980; Slattery and Sinclair, 1983; Kim and Shelef, 1986; Skarpeid et al., 1998). Compared to SDS-PAGE, IEF generally presents better band 
resolution, but gives more complicated and less consistent patterns, which also advises against its use for the authentication of processed meat products. Better results can be achieved by means of 2-DE coupled to image analysis software since it allows the separation of thousands of proteins in one gel and analysis of changes in protein expression levels, such as isoforms and posttranslational modifications (Montowska and Pospiech, 2012b). Species-specific differences in the molecular weight and isoelectric point of skeletal muscle myosin light chain (MLC) isoforms of six species, namely, cow, pork, chicken, turkey, duck, and goose, were revealed by 2-DE (Montowska and Pospiech, 2011b). The authors concluded that each species showed a characteristic pattern on 2-DE gels that can be used for species identification in raw meat mixtures since even a $2 \%$ difference in the sequences of MLC resulted in different electrophoretic mobilities. Later, the same methodology was applied to investigate if the interspecies differences noticed in the expression of MLC isoforms in raw meat were also observed in minced meat and meat products (frankfurters and sausages) produced from the same six species (Montowska et al., 2012b). The results showed that the MLC suffered only a relatively small degradation after processing, enabling species identification in all samples when the combination of all the three MLC isoforms was taken into account, and as long as the content of meat of one species in the mixture was not lower than $10 \%$. Thus, the authors concluded that MLC isoforms have the potential to be used as markers for the authentication of meat products made from the analyzed species.

As an alternative to gel electrophoresis, capillary electrophoresis (CE) has also been applied to meat species authentication studies since it offers high resolving power and sensitivity in protein analysis. A CE-SDS methodology, developed by Cota-Rivas and Vallejo-Cordoba (1997) for the analysis of sarcoplasmic proteins, revealed the existence of qualitative and quantitative differences in raw beef, pork, and turkey meat. Linear discriminant analysis (LDA) was later used by the same authors for the interpretation of the quantitative data obtained by CE-SDS (Vallejo-Cordoba and Cota-Rivas, 1998). The correct classification given by LDA on water-soluble protein data was $100 \%$ for all meat species except pork (94\%). The same group also proposed the use of CE for the discrimination of bovine and ostrich meats (Vallejo-Cordoba et al., 2010). Although the applicability of CE methodology for meat species differentiation was suggested, in both studies the authors only tested a limited number of meat samples ( $n=42$ in total for beef, pork, and turkey samples and $n=20$ for beef and ostrich), thus further work should be performed using samples from different animals and tissues to confirm these results. Since only fresh meat was used in both studies, the proposed CE methodologies seem to be applicable only for the authentication of raw meat. Moreover, they do not seem adequate for species identification or quantification in meat mixtures since species discrimination was mainly based on quantitative profiles of proteins that are common to different species.

\subsubsection{Immunochemical Techniques}

Immunochemical assays are based on the specific reaction between antibodies and antigens and are frequently used for meat species authentication. The enzyme-linked 
immunosorbent assay (ELISA) is the most widely used immunochemical technique. ELISA presents several advantages, such as its simplicity and easy implementation because it does not require expensive equipment or specialized technicians, it has high specificity, high sensitivity, and high throughput, and is thus very suitable for routine application in quality control laboratories (Asensio et al., 2008). On the other hand, the performance of the assay depends on the availability and specificity of the chosen antibody to detect a particular species. Both polyclonal and monoclonal antibodies have been used in ELISA for food authentication. The former offers the advantage of recognizing different epitopes of the antigens, being more tolerant to small changes in the nature of the antigen, but more prone to cross-reactivity with other species, in particular with those that are closely related. This explains the differences between different commercial kits available for the detection of poultry meat, instead of specifically identifying the presence of chicken or turkey. Another limitation of ELISA regards the identification of species in processed meat products since proteins can suffer denaturation that leads to specific epitope alterations (Hird et al., 2005) and consequent decreased sensitivity or even false negatives. Moreover, potential target proteins for ELISA are often irreversibly aggregated, insoluble, and difficult to extract in highly processed products (Taylor et al., 2009; Kotoura et al., 2012). To overcome this drawback, the use of antibodies raised against heat-resistant muscle proteins, such as skeletal muscle protein troponin I, has been proposed in different reports (Chen et al., 1998; Chen and Hsieh, 2000; Djurdjevic et al., 2005; Liu et al., 2006; Zvereva et al., 2015). Currently, polyclonal antibodies raised against heat-resistant speciesspecific muscle-related glycoproteins are included in several commercial kits, which are being used by regulatory agencies to detect meat species adulteration and to enforce national and transnational laws and regulations (Asensio et al., 2008). These kits are, in general, marketed to meet or exceed the United States Department of Agriculture Food Safety and Inspection Service protocol standards for the Cooked Meat Species ELISA. Nonetheless, commercial kits should be used only for qualitative purposes because limits of detection in processed foods can vary with fat content, degree of thermal processing, tissue, and maturation of meat. Giovannacci et al. (2004) applied different commercial ELISA kits for the identification of beef, sheep, pork, and poultry in 40 commercial canned products and found that half of those were in good agreement with the label, while the others failed because of the presence of undeclared species. Similarly, López et al. (2011) applied different commercial ELISA kits for meat species identification in several cooked meat products, including sausages and hams, either produced in pilot plants or acquired in supermarkets. The methodology allowed identification of all animal species described on the labels. The same samples were also evaluated by SDS-PAGE, which failed to detect some of the species in some of the samples, possibly because they were only present in low amounts.

A later study by Kotoura et al. (2012) proposed the use of different monoclonal antibodies, raised to detect SDS-denatured proteins, to accurately determine the beef content in model processed foods and some commercial foods. The proposed method comprised a sandwich ELISA using two types of monoclonal antibodies, one raised against denatured beef myoglobin and another against a unique amino acid sequence of beef myoglobin. This system allowed the determination of beef content in chicken 
or pork meats, irrespective of the processing conditions; no cross-reactivity with other food proteins, such as pork, chicken, egg, milk, wheat, buckwheat, peanut, shrimp, and crab was detected, though some cross-reactivity occurred with lamb.

\subsubsection{Chromatographic and Mass Spectrometry Techniques}

As alternative protein-based methods, several studies suggest the use of chromatographic techniques, mainly high-performance liquid chromatography (HPLC) coupled with different detectors and liquid chromatography (LC) hyphenated with different MS detectors. Giaretta et al. (2013) proposed an anionic exchange ultraperformance liquid chromatography (UPLC) coupled with diode-array detection for the separation of myoglobin from raw meat samples of beef, chicken, horse, ostrich, pork, and water buffalo. Previous to the UPLC analysis, samples were treated with sodium nitrite to transform oxymyoglobin and deoxymyoglobin to the more stable metmyoglobin and desalified on a PD-10 column. This methodology allowed the detection of $5 \%(\mathrm{w} / \mathrm{w})$ of pork in raw beef burgers. Although exhibiting low sensitivity and possibly being only suited for the analysis of raw meat, the authors pointed out the simplicity of the method and the use of equipment that is commonly present in quality control laboratories as advantages. HPLC coupled to electrochemical analysis was proposed by Hung et al. (2011) to directly detect peptides and amino acids that exhibit little or no chromogenic behavior. The authors used a novel copper nanoparticleplated screen-printed electrode, which allowed the selective detection of amino acids and small peptides in protein-rich matrices, while being insensitive to large proteins. This methodology allowed the differentiation of ostrich from pork, beef, and chicken meat based on the chromatographic profiles that presented characteristic peaks of lysine, glutamine, carnosine, and anserine. However, this work only described its application to differentiate raw meats, each containing single species and without mentioning the number of samples used for each species and other variability factors (eg, with different age, sex, breeds) within each species.

More recently, modern proteomics has taken advantage of equipment advances, namely, the development of soft ionization techniques, such as matrix-assisted laser desorption ionization (MALDI) and electrospray ionization (ESI) that allow the accurate analysis of peptides by MS methods and, consequently, their use as reliable biomarkers for meat authentication purposes (Sentandreu and Sentandreu, 2014). Although other protein-based methods present drawbacks regarding the analysis of processed meat products, the use of specific peptide markers is related to the primary structure of proteins, which is known to be relatively resistant to processing (Buckley et al., 2013; Sentandreu and Sentandreu, 2011). Authentication methods based on peptide identification by MS can also allow differentiation between tissues of the same species when targeting tissue-specific peptide sequences (Sentandreu and Sentandreu, 2014). Moreover, since high mass accuracy and high sensitivity can be achieved with modern mass spectrometers, this approach generally allows the detection of low amounts of undeclared species in meat products (Sentandreu and Sentandreu, 2014). Nevertheless, the high cost of equipment, the need for specialized technicians, and 
the duration of the analysis, very important in the case of perishable foods, are seen as disadvantages.

The use of MS for peptide identification is frequently coupled to a previous separation step by LC. Sentandreu et al. (2010) proposed a methodology for the detection of chicken meat in mixed meats that comprised the extraction of myofibrillar proteins, the enrichment of target proteins by OFFGEL isoelectric focusing, in-solution trypsin digestion of MLC3, and the analysis of the generated peptides by LC-MS/MS. Based on the results obtained by SDS-PAGE and MALDI-TOF MS analysis, MLC3 was selected because of its heat stability. An enrichment step by OFFGEL fractionation was included to lower the detection limit of the method. Selection of heat-stable peptides from chicken MLC3 and the use of stable isotope-labeled peptides allowed the quantitative detection of $0.5 \%(\mathrm{w} / \mathrm{w})$ of chicken in mixtures with pork meat. The authors considered that, once optimized, the whole protocol has the potential to be carried out within 3-4 days, which is still a very long period when compared to the most commonly used DNA-based methods.

The use of LC-MS/MS with a multiple reaction monitoring (MRM) method for the identification of specific peptides was also proposed for the identification of horse and pork in halal beef (von Bargen et al., 2013) and in highly processed foods (von Bargen et al., 2014). The method allowed detection of $0.55 \%(\mathrm{w} / \mathrm{w})$ of horse or pork in beef, or down to $0.13 \%$ pork in beef when $\mathrm{MRM}^{3}$ and a micro-LC system were applied (von Bargen et al., 2013). Since the selected marker peptides were proven to be sufficiently stable to heat processing, the same methodology was further used for the identification of pork and horse meat in highly processed foods (von Bargen et al., 2014). In this study, the authors also developed a rapid 2-min extraction protocol that allowed an efficient protein extraction from many types of sample, including highly processed foods. The method was able to detect pork and horse meat down to $0.24 \%$ (w/w) in a beef meat matrix and was further applied to commercial products, including salami, sausages, meatballs, canned meat, and Frikandeln. All samples were found to be in agreement with the labeled information, with the exception of one declaring only beef in which horse-specific peptides were detected and further confirmed by droplet digital PCR. The authors suggested that the proposed methodology could be easily applicable in routine control laboratories since it is fast and does not require any sample pretreatment or concentration by SDS-PAGE or OFFGEL fractionation.

The use of ambient MS techniques, namely, liquid extraction surface analysis mass spectrometry (LESA-MS) using tandem electrospray MS, without needing previous chromatographic separation, was proposed as fast approaches for the discrimination of five meat species, namely, pork, beef, horse, chicken, and turkey (Montowska et al., 2014a,b; Fig. 14.1). LESA-MS/MS allowed the identification of species in mixtures of cooked meat, namely, the detection of $10 \%(\mathrm{w} / \mathrm{w})$ of cooked pork, horse, or turkey meats in a beef matrix and $5 \%(\mathrm{w} / \mathrm{w})$ of chicken in beef. The method involved a washing step to remove salts and fats that interfere with efficient ionization, followed by digestion and direct ionization of dried in-solution tryptic digests from a polymer surface by LESA-MS, which was significantly faster than other proteomic approaches. According to the authors, the time of analysis could be shortened to approximately $1 \mathrm{~h}$ by applying microwaves or ultrasonication during the digestion process. On the other 

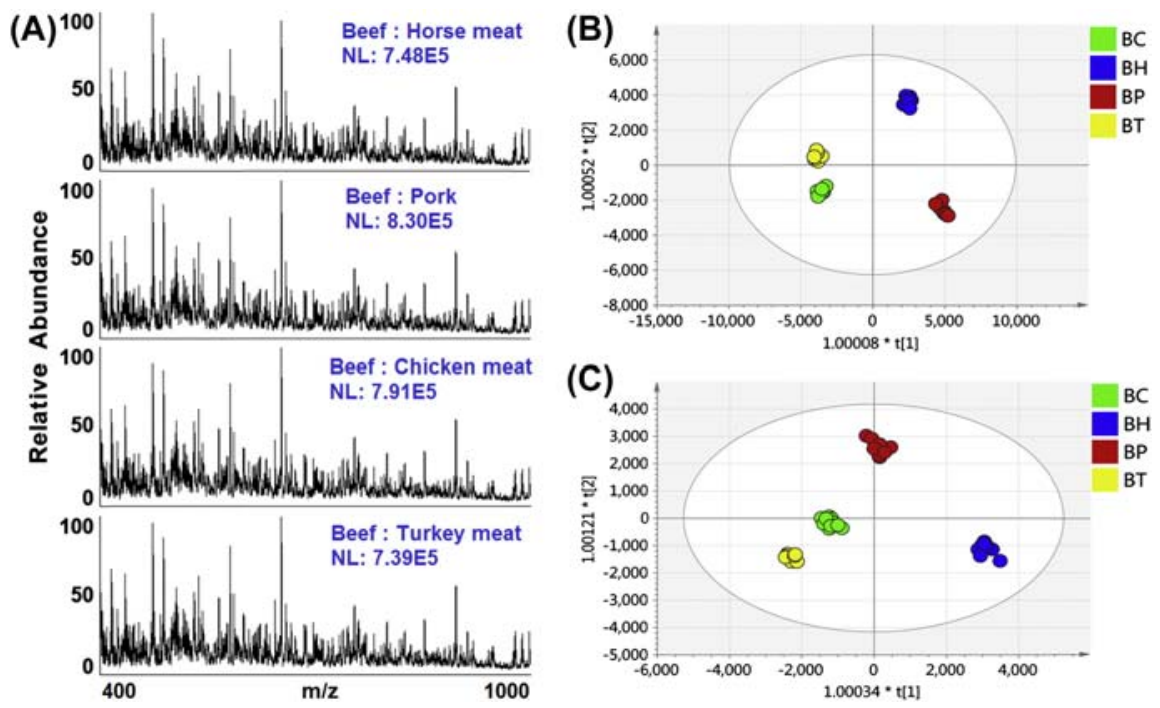

Figure 14.1 Distinguishing meat species in cooked beef. (A) Liquid extraction surface analysis mass spectrometry (LESA-MS) average mass spectra of tryptic digests of cooked meat mixtures of beef spiked with $1 \%(\mathrm{w} / \mathrm{w})$ of horse, pork, chicken, and turkey meat. Orthogonal partial least squares discriminant analysis (OPLS-DA) score plots of datasets collected from beef spiked with $10 \%$ (B) and $1 \%$ (C) of the second meat species, $m / z$ 400-1000, $n=50$. $B C$, Beef/chicken meat; $B H$, beef/horse meat; $B P$, beef/pork; $B T$, beef/turkey meat. Reprinted with permission from Montowska, M., Alexander, M.R., Tucker, G.A., Barrett, D.A., 2014b. Rapid detection of peptide markers for authentication purposes in raw and cooked meat using ambient liquid extraction surface analysis mass spectrometry. Analytical Chemistry (86), 10257-10265. Copyright (C) 2014 American Chemical Society.

hand, the sensitivity of this methodology was much lower when compared to LC-MS/ MS (Table 14.1). Applicability of the LESA-MS/MS method was later assessed by the same group to identify different peptide markers in several types of processed meat products, including commercial samples and in-house prepared reference sausages. Results showed that three samples were mislabeled, one pork sausage declaring veal that presented only peptide markers for pork species and two cocktail sausage samples that declared turkey that was not detected. Nevertheless, the authors stated that, considering the low sensitivity of the LESA-MS/MS method, the possibility that the meat content was below the limit of detection could not be excluded. Additionally, a sample of horse sausage was also positive for pork meat.

\subsection{DNA-Based Methods}

Analytical techniques relying on DNA-based methods have rapidly evolved during recent years as alternatives to overcome the limitations of protein analysis. Compared to protein-based methods, they present several advantages, specifically the ubiquity of 
Table 14.1 Summarized Information About Protein-Based Methods Applied to Meat Species Detection

\begin{tabular}{|c|c|c|c|c|c|}
\hline Method & Target Species & Target Molecule & Type of Product & Sensitivity & References \\
\hline 2-DE & $\begin{array}{l}\text { Cattle, pork, } \\
\text { chicken, } \\
\text { turkey, duck, } \\
\text { and goose }\end{array}$ & Myosin light chain isoforms & Raw meat & - & $\begin{array}{l}\text { Montowska and } \\
\text { Pospiech } \\
\text { (2011b) }\end{array}$ \\
\hline 2-DE & $\begin{array}{l}\text { Cattle, pork, } \\
\text { chicken, } \\
\text { turkey, duck, } \\
\text { and goose }\end{array}$ & Myosin light chain isoforms & $\begin{array}{l}\text { Minced meat } \\
\text { mixtures, } \\
\text { processed } \\
\text { meat products } \\
\text { (frankfurters } \\
\text { and sausages) }\end{array}$ & $\begin{array}{l}\text { Not determined, but content of meat of } \\
\text { one species in the mixture should } \\
\text { be }<10 \%(\mathrm{w} / \mathrm{w})\end{array}$ & $\begin{array}{l}\text { Montowska and } \\
\text { Pospiech } \\
\text { (2012b) }\end{array}$ \\
\hline $\mathrm{CE}$ & $\begin{array}{c}\text { Cattle and } \\
\text { ostrich }\end{array}$ & $\begin{array}{l}\text { Water-soluble protein and salt soluble } \\
\text { protein fractions }\end{array}$ & Raw meat & - & $\begin{array}{l}\text { Vallejo-Cordoba } \\
\text { et al. (2010) }\end{array}$ \\
\hline $\begin{array}{l}\text { ELISA with } \\
\text { monoclonal } \\
\text { antibodies }\end{array}$ & $\begin{array}{l}\text { Chicken and } \\
\text { turkey }\end{array}$ & $\begin{array}{l}\text { Thermostable soluble muscle proteins in } \\
\text { chicken }(35,30,25 \text {, and } 23.5 \mathrm{kDa}) \\
\text { and turkey }(29.5,26,24.5 \text {, and } \\
22 \mathrm{kDa})\end{array}$ & $\begin{array}{l}\text { Cooked }\left(100^{\circ} \mathrm{C} \text {, }\right. \\
15 \text { min }) \\
\text { mammalian } \\
\text { meat (pork, } \\
\text { cattle, lamb, } \\
\text { horse, deer) }\end{array}$ & $\begin{array}{l}1 \% \text { (chicken in cooked beef or chicken } \\
\text { in cooked pork) }\end{array}$ & $\begin{array}{l}\text { Djurdjevic et al. } \\
\quad(2005)\end{array}$ \\
\hline $\begin{array}{l}\text { Sandwich } \\
\text { ELISA with } \\
\text { monoclonal } \\
\text { antibodies }\end{array}$ & Pork & Skeletal muscle troponin I & $\begin{array}{l}\text { Raw and heat- } \\
\text { processed } \\
\text { meat mixtures }\end{array}$ & $\begin{array}{l}0.05 \%(\mathrm{w} / \mathrm{w}) \text { (raw, cooked, or } \\
\text { autoclaved pork in chicken), } 0.05 \% \\
(\mathrm{w} / \mathrm{w}) \text { (raw pork in beef), and } 0.1 \% \\
(\mathrm{w} / \mathrm{w}) \text { (cooked or autoclaved pork } \\
\text { in beef mixtures) }\end{array}$ & Liu et al. (2006) \\
\hline $\begin{array}{l}\text { ELISA with } \\
\text { monoclonal } \\
\text { antibodies }\end{array}$ & Cattle & $\begin{array}{l}\text { SDS-denatured beef myoglobin and } \\
\text { peptide with an amino acid sequence } \\
\text { unique to beef myoglobin }\end{array}$ & $\begin{array}{l}\text { Raw and cooked } \\
\text { meat }\end{array}$ & $\begin{array}{l}9.5 \mathrm{ng} / \mathrm{mL} \text { (detection); } 12.8 \mathrm{ng} / \mathrm{mL} \\
\quad \text { (quantification) }\end{array}$ & $\begin{array}{l}\text { Kotoura et al. } \\
\text { (2012) }\end{array}$ \\
\hline $\begin{array}{r}\text { Sandwich } \\
\text { ELISA }\end{array}$ & $\begin{array}{l}\text { Mammalian } \\
\text { (cattle, pork, } \\
\text { lamb, and } \\
\text { horse) }\end{array}$ & Skeletal muscle protein troponin I & $\begin{array}{l}\text { Raw meat and } \\
\text { meat products }\end{array}$ & $\begin{array}{l}4.8 \mathrm{ng} / \mathrm{mL} \text { (detection); } 8.7-52 \mathrm{ng} / \mathrm{mL} \\
\quad \text { (quantification range) }\end{array}$ & $\begin{array}{l}\text { Zvereva et al. } \\
\qquad(2015)\end{array}$ \\
\hline
\end{tabular}


Table 14.1 Summarized Information About Protein-Based Methods Applied to Meat Species

Detection-cont'd

\begin{tabular}{|c|c|c|c|c|c|}
\hline Method & Target Species & Target Molecule & Type of Product & Sensitivity & References \\
\hline $\begin{array}{l}\text { OFFGEL } \\
\text { isoelectric } \\
\text { focusing } \\
\text { fractionation } \\
\text { and LC-ESI- } \\
\text { MS/MS }\end{array}$ & Chicken & $\begin{array}{l}\text { Two peptides (DQGTFEDFVEGLR } \\
\text { and ALGQNPTNAEINK) from } \\
\text { myosin light chain } 3\end{array}$ & $\begin{array}{l}\text { Raw and cooked } \\
\text { meat }\end{array}$ & $\begin{array}{l}0.5 \%(\mathrm{w} / \mathrm{w}) \text { (chicken in pork meat; } \\
\text { quantification using stable isotope- } \\
\text { labeled peptides as internal } \\
\text { standard) }\end{array}$ & $\begin{array}{l}\text { Sentandreu et al. } \\
\text { (2010) }\end{array}$ \\
\hline $\begin{array}{l}\text { LC-MS/MS } \\
\text { and micro } \\
\text { LC-MS/MS } \\
\text { using MRM } \\
\text { and } \mathrm{MRM}^{3}\end{array}$ & Horse and pork & $\begin{array}{l}\text { Peptides YDIINLR from troponin T, } \\
\text { TLAFLFAER from myosin-4, and } \\
\text { EFEIGNLQSK from myosin-2 }\end{array}$ & Raw meat & $\begin{array}{l}0.55 \%(\mathrm{w} / \mathrm{w}) \text { (horse or pork in beef) } \\
0.13 \%(\mathrm{w} / \mathrm{w})(\text { pork in beef using } \\
\left.\text { micro-LC and } \mathrm{MRM}^{3}\right)\end{array}$ & $\begin{array}{l}\text { Von Bargen et al. } \\
\text { (2013) }\end{array}$ \\
\hline $\begin{array}{l}\text { HPLC-MS/MS } \\
\text { using MRM } \\
\text { and } \mathrm{MRM}^{3}\end{array}$ & Horse and pork & $\begin{array}{l}\text { Peptides YDIINLR from troponin T, } \\
\text { TLAFLFAER from myosin-4, } \\
\text { SALAHAVQSSR from myosin-1 } \\
\text { and -4, EFEIGNLQSK from myosin- } \\
\text { 2, and LVNDLTGQR from myosin-1 }\end{array}$ & $\begin{array}{l}\text { Processed food } \\
\text { matrices }\end{array}$ & $0.24 \%(\mathrm{w} / \mathrm{w})$ (horse or pork in beef) & $\begin{array}{l}\text { Von Bargen et al. } \\
\text { (2014) }\end{array}$ \\
\hline LESA-MS/MS & $\begin{array}{l}\text { Horse, pork, } \\
\text { chicken, and } \\
\text { turkey }\end{array}$ & $\begin{array}{l}\text { Several heat-stable peptides from } \\
\text { MLC1/3f, MLC2f, troponin C, } \\
\text { myoglobin, myosin- } 1 \text {, or myosin- } 4\end{array}$ & Cooked meat & $\begin{array}{l}10 \%(\mathrm{w} / \mathrm{w})(\text { cooked pork, horse, or } \\
\text { turkey meat), } 5 \%(\mathrm{w} / \mathrm{w}) \text { (chicken } \\
\text { meat in beef) }\end{array}$ & $\begin{array}{l}\text { Montowska et al. } \\
\text { (2014b) }\end{array}$ \\
\hline LESA-MS/MS & $\begin{array}{l}\text { Horse, pork, } \\
\text { chicken, } \\
\text { turkey, and } \\
\text { cattle }\end{array}$ & 25 species-specific heat-stable peptides & $\begin{array}{l}\text { Processed meat } \\
\text { products }\end{array}$ & - & $\begin{array}{l}\text { Montowska et al. } \\
\text { (2015) }\end{array}$ \\
\hline
\end{tabular}

2-DE, Two-dimensional electrophoresis; $C E$, capillary electrophoresis; ELISA, enzyme-linked immunosorbent assay; HPLC-MS/MS, high-performance liquid chromatography tandem mass spectrometry; $L C-M S / M S$, liquid chromatography tandem mass spectrometry; $L C$-ESI-MS/MS, liquid chromatography electrospray ionization tandem mass spectrometry; LESA-MS/MS, liquid extraction surface analysis tandem mass spectrometry; $M L C$, myosin light chain; $M R M$, multiple reaction monitoring; SDS, sodium dodecyl sulfate. 
nucleic acids in every type of cell and their greater stability than proteins. Most DNAbased methods rely on the polymerase chain reaction (PCR) technique for its specificity, sensitivity, simplicity, and rapidity, allowing the identification of species of origin even in complex and processed foods. Specificity of PCR assays is related to the target sequences based on the appropriate primer choice. For accurate species identification, the primers should be designed or selected after adequate in silico and in vitro analysis to confirm their specificity. Both nuclear and mitochondrial genes can be targeted as species-specific DNA markers. Mitochondrial DNA (mtDNA) is several-fold more abundant than nuclear, increasing the sensitivity of PCR assays because of the high number of mtDNA copies per cell. Besides, mtDNA evolves much faster than nuclear DNA, containing more sequence diversity that enables the identification of phylogenetically related taxa (Fajardo et al., 2010; Girish et al., 2005).

PCR amplification is based on hybridization of specific primers that flank a target DNA sequence followed by in vitro synthesis to form millions of copies. DNA amplification followed by agarose gel electrophoresis to verify fragment size is the simplest PCR approach to detect the presence of a certain meat species (Fajardo et al., 2010). Depending on the genetic marker or the aim of the analysis, additional methods can complement the analysis of PCR products, such as sequencing and restriction fragment length polymorphism (RFLP). The vast majority of PCR methods is based on species-specific primers by means of end-point PCR, multiplex PCR, and real-time PCR (Ballin et al., 2009; Fajardo et al., 2010). The use of short arbitrary primers to generate fingerprint patterns of random amplified polymorphic DNA (RAPD) has been applied to species identification of meats, taking advantage of the fact that prior knowledge of the target sequence is not required (Arslan et al., 2005; Calvo et al., 2001; Rastogi et al., 2007). However, difficulties in obtaining reproducible patterns and the inappropriateness of analyzing admixed meat species make the applicability of RAPD of limited scope in the case of processed foods (Fajardo et al., 2010). Other fingerprint DNA-based methods, such as single sequence repeats (SSRs) or microsatellites, single nucleotide polymorphisms (SNPs), and PCR with single-strand conformation polymorphisms (SSCPs) have also been used for meat species differentiation. Analysis of SSR markers facilitated the discrimination of pork from wild boar, both of which belong to the same species (Sus scrofa) and therefore are very difficult to differentiate (Conyers et al., 2012). SNP represents a promising molecular method for meat species traceability, as described by Yang et al. (2014). PCR-SSCP with capillary electrophoresis targeting the mitochondrial 12S rRNA gene was successfully developed and applied to differentiate eight avian species based on their distinct patterns (Tisza et al., 2016).

\subsubsection{PCR-RFLP}

PCR followed by RFLP analysis relies on specific restriction sites recognized by the restriction enzymes, allowing species identification based on the different patterns obtained (Ballin et al., 2009). This technique has been largely applied to meat and meat product speciation and has the ability to differentiate closely related species (Fajardo et al., 2010). The advantages of PCR-RFLP are related to its simplicity, low cost, and 
suitability for routine analysis (Pfeiffer et al., 2004). On the contrary, the possible existence of intraspecific mutations at restriction sites (Pereira et al., 2008), the presence of mixed species, and processing are likely to constrain the application of PCR-RFLP in meat product authentication (Fajardo et al., 2010).

Table 14.2 summarizes the most relevant information from reported PCR-RFLP methods, from which it can be inferred that mtDNA markers are mostly targeted to differentiate domestic and game meat species. Most PCR-RFLP methods use gel

\section{Table 14.2 Summarized Information About Methods of PCR-RFLP Applied to Meat Species Detection}

\begin{tabular}{|c|c|c|c|c|}
\hline Target Species & Application & Target Gene & Sensitivity & References \\
\hline $\begin{array}{l}\text { Pork, cattle, wild boar, } \\
\text { buffalo, sheep, goat, } \\
\text { horse, chicken, } \\
\text { turkey, red deer, roe } \\
\text { deer, moose, } \\
\text { antelope, chamois, } \\
\text { mouflon, and } \\
\text { kangaroo }\end{array}$ & $\begin{array}{l}\text { Sausages, } \\
\text { marinated and } \\
\text { heat-treated } \\
\text { meats }\end{array}$ & Cytochrome b & $\begin{array}{l}<1 \%(\text { w/w) } \\
\quad \text { (pork) }\end{array}$ & $\begin{array}{l}\text { Meyer et al. } \\
\text { (1995) }\end{array}$ \\
\hline Red deer and sika deer & $\begin{array}{l}\text { Raw and heat- } \\
\text { treated meats }\end{array}$ & Cytochrome b & - & $\begin{array}{l}\text { Matsunaga et al. } \\
\text { (1998) }\end{array}$ \\
\hline $\begin{array}{l}\text { Buffalo, cattle, sheep, } \\
\text { goat, hare, red deer, } \\
\text { fallow deer, moose, } \\
\text { antelope, gazelle, } \\
\text { wildebeest, } \\
\text { chamois, Pyrenean } \\
\text { ibex, and kangaroo }\end{array}$ & $\begin{array}{l}\text { Frozen meat and } \\
\text { lyophilized } \\
\text { protein } \\
\text { extracts }\end{array}$ & Cytochrome b & - & $\begin{array}{l}\text { Wolf et al. } \\
\text { (1999) }\end{array}$ \\
\hline Pork & $\begin{array}{l}\text { Meat, } \\
\text { mortadella, } \\
\text { pork sausage, } \\
\text { and dry-cured } \\
\text { ham }\end{array}$ & D-loop & $\begin{array}{c}5 \%(\mathrm{w} / \mathrm{w}) \\
\text { (pork) }\end{array}$ & $\begin{array}{l}\text { Montiel-Sosa } \\
\text { et al. (2000) }\end{array}$ \\
\hline Ostrich & $\begin{array}{l}\text { Raw and heat- } \\
\text { treated meats }\end{array}$ & Cytochrome b & - & $\begin{array}{l}\text { Abdulmawjood } \\
\text { and Buelte } \\
\text { (2002) }\end{array}$ \\
\hline $\begin{array}{l}\text { Cattle, goat, sheep, } \\
\text { pork, quail, wild } \\
\text { boar, chicken, } \\
\text { turkey, red deer, and } \\
\text { roe deer }\end{array}$ & $\begin{array}{l}\text { Chicken nuggets, } \\
\text { hamburgers, } \\
\text { croquettes, } \\
\text { sausages, } \\
\text { ham, } \\
\text { tortellini, } \\
\text { moussaka, } \\
\text { pâté, ravioli, } \\
\text { and } \\
\text { cannelloni }\end{array}$ & Cytochrome b & - & $\begin{array}{l}\text { Pascoal et al. } \\
\text { (2004) }\end{array}$ \\
\hline
\end{tabular}


Table 14.2 Summarized Information About Methods of PCR-RFLP Applied to Meat Species Detection-cont'd

\begin{tabular}{|c|c|c|c|c|}
\hline Target Species & Application & Target Gene & Sensitivity & References \\
\hline $\begin{array}{l}\text { Cattle, sheep, goat, red } \\
\text { deer, and roe deer }\end{array}$ & Blood and tissue & D-loop & - & $\begin{array}{l}\text { Pfeiffer et al. } \\
\text { (2004) }\end{array}$ \\
\hline $\begin{array}{l}\text { Cattle, buffalo, sheep, } \\
\text { and goat }\end{array}$ & $\begin{array}{l}\text { Raw and heat- } \\
\text { treated meats, } \\
\text { and fried meat } \\
\text { products }\end{array}$ & $12 \mathrm{~S}$ rRNA & - & $\begin{array}{l}\text { Girish et al. } \\
\quad(2005)\end{array}$ \\
\hline Pork & $\begin{array}{l}\text { Raw meats and } \\
\text { fats (halal) }\end{array}$ & Cytochrome b & - & $\begin{array}{l}\text { Aida et al. } \\
\text { (2005) }\end{array}$ \\
\hline $\begin{array}{l}\text { Cattle, sheep, goat, red } \\
\text { deer, fallow deer, } \\
\text { and roe deer }\end{array}$ & $\begin{array}{l}\text { Raw and heat- } \\
\text { treated meats }\end{array}$ & 12S rRNA & - & $\begin{array}{l}\text { Fajardo et al. } \\
\text { (2006) }\end{array}$ \\
\hline $\begin{array}{l}\text { Cattle, sheep, goat, } \\
\text { pork, horse, poultry, } \\
\text { and deer }\end{array}$ & Raw meats & Cytochrome b & $\begin{array}{l}1 \%(\mathrm{w} / \mathrm{w}) \\
\quad \text { (beef and } \\
\text { horse) }\end{array}$ & Maede (2006) \\
\hline $\begin{array}{l}\text { Chicken, duck, turkey, } \\
\text { guinea fowl, and } \\
\text { quail }\end{array}$ & $\begin{array}{l}\text { Raw meats, heat- } \\
\text { treated meats, } \\
\text { and fried } \\
\text { croquettes }\end{array}$ & 12S rRNA & - & $\begin{array}{l}\text { Girish et al. } \\
\text { (2007) }\end{array}$ \\
\hline $\begin{array}{l}\text { Chamois, Pyrenean } \\
\text { ibex, mouflon, } \\
\text { cattle, sheep, and } \\
\text { goat }\end{array}$ & $\begin{array}{l}\text { Raw and heat- } \\
\text { treated meats }\end{array}$ & $\begin{array}{l}\text { 12S rRNA, } \\
\text { D-loop }\end{array}$ & - & $\begin{array}{l}\text { Fajardo et al. } \\
\text { (2007a) }\end{array}$ \\
\hline Pork and wild boar & Raw meats & $\mathrm{MC} 1 \mathrm{R}$ & - & $\begin{array}{l}\text { Fajardo et al. } \\
\text { (2008) }\end{array}$ \\
\hline $\begin{array}{l}\text { Quail, pheasant, red- } \\
\text { legged partridge, } \\
\text { guinea fowl, } \\
\text { capercaillie, } \\
\text { Eurasian woodcock, } \\
\text { woodpigeon, and } \\
\text { song thrush }\end{array}$ & Raw meats & $12 \mathrm{~S}$ rRNA & - & $\begin{array}{l}\text { Rojas et al. } \\
\text { (2008) }\end{array}$ \\
\hline $\begin{array}{l}\text { Red deer, fallow deer, } \\
\text { roe deer, chamois, } \\
\text { mouflon, Pyrenean } \\
\text { ibex, goat, cattle, } \\
\text { sheep, and swine }\end{array}$ & Raw meats & $12 \mathrm{~S}$ rRNA & - & $\begin{array}{l}\text { Fajardo et al. } \\
\qquad(2009 \mathrm{a}, \mathrm{b})\end{array}$ \\
\hline $\begin{array}{l}\text { Quail, pheasant, red- } \\
\text { legged partridge, } \\
\text { chukar partridge, } \\
\text { guinea fowl, } \\
\text { capercaillie, }\end{array}$ & Raw meats & D-loop & - & $\begin{array}{l}\text { Rojas et al. } \\
\text { (2009a) }\end{array}$ \\
\hline
\end{tabular}


Table 14.2 Summarized Information About Methods of PCR-RFLP Applied to Meat Species Detection-cont'd

\begin{tabular}{|c|c|c|c|c|}
\hline Target Species & Application & Target Gene & Sensitivity & References \\
\hline \multicolumn{5}{|l|}{$\begin{array}{l}\text { Eurasian woodcock, } \\
\text { and woodpigeon }\end{array}$} \\
\hline $\begin{array}{l}\text { Cattle, pork, buffalo, } \\
\text { quail, chicken, goat, } \\
\text { and rabbit }\end{array}$ & Raw meats & Cytochrome b & - & $\begin{array}{l}\text { Murugaiah et al. } \\
\text { (2009) }\end{array}$ \\
\hline $\begin{array}{l}\text { Chicken, turkey, duck, } \\
\text { goose, pheasant, } \\
\text { partridge, } \\
\text { woodcock, ostrich, } \\
\text { quail, and song } \\
\text { thrush }\end{array}$ & $\begin{array}{l}\text { Raw and heat- } \\
\text { treated meats }\end{array}$ & $\begin{array}{l}\text { 12S rRNA, } \\
\text { Cytochrome b }\end{array}$ & - & $\begin{array}{l}\text { Stamoulis et al. } \\
\text { (2010) }\end{array}$ \\
\hline $\begin{array}{c}\text { Cattle, chicken, turkey, } \\
\text { sheep, pork, buffalo, } \\
\text { camel, and donkey }\end{array}$ & $\begin{array}{l}\text { Raw meats and } \\
\text { blood }\end{array}$ & $\begin{array}{l}\text { Cytochrome c } \\
\text { oxidase } \\
\text { subunit } 1\end{array}$ & - & $\begin{array}{l}\text { Haider et al. } \\
\qquad(2012)\end{array}$ \\
\hline Pork & $\begin{array}{l}\text { Meatballs, } \\
\text { streaky } \\
\text { beacon, } \\
\text { frankfurters, } \\
\text { and burgers }\end{array}$ & Cytochrome b & $\begin{array}{l}0.01 \%(\mathrm{w} / \mathrm{w}) \\
\quad \text { (pork) } \\
0.0001 \mathrm{ng} \\
\quad \text { pork } \\
\text { DNA) }\end{array}$ & $\begin{array}{l}\text { Ali et al. } \\
\qquad(2012 a)\end{array}$ \\
\hline $\begin{array}{l}\text { Cattle, buffalo, goat, } \\
\text { sheep, and pork }\end{array}$ & Raw meats & Cytochrome b & - & $\begin{array}{l}\text { Kumar et al. } \\
\qquad(2014)\end{array}$ \\
\hline $\begin{array}{l}\text { Cattle, sheep, pork, } \\
\text { chicken, donkey, } \\
\text { and horse }\end{array}$ & $\begin{array}{l}\text { Raw meats, } \\
\text { sausages, } \\
\text { frankfurters, } \\
\text { hamburgers, } \\
\text { and hams }\end{array}$ & Cytochrome b & - & $\begin{array}{l}\text { Doosti et al. } \\
\text { (2014) }\end{array}$ \\
\hline Cat & $\begin{array}{l}\text { Raw, heat- } \\
\text { treated meats } \\
\text { and meatballs }\end{array}$ & $18 \mathrm{~S}$ rRNA & $0.01 \%(w / w)$ & $\begin{array}{l}\text { Ali et al. } \\
\qquad(2015 \mathrm{a})\end{array}$ \\
\hline Dog & $\begin{array}{l}\text { Burger } \\
\text { formulations } \\
\text { and } \\
\text { commercial } \\
\text { burgers }\end{array}$ & Cytochrome b & $\begin{array}{l}0.01 \%(\mathrm{w} / \mathrm{w}) \\
0.0001 \mathrm{ng} \\
\text { (dog } \\
\text { DNA) }\end{array}$ & $\begin{array}{l}\text { Rahman et al. } \\
\qquad(2015)\end{array}$ \\
\hline
\end{tabular}

$M C 1 R$, Melanocortin receptor 1 gene; PCR-RFLP, polymerase chain reaction restriction fragment length polymorphism.

electrophoresis as a simple and economic strategy to analyze fragment patterns. More recently, chip-based capillary electrophoresis has emerged as an alternative to conventional electrophoresis for RFLP analysis for meat authentication, producing higher resolution band patterns, shorter analysis times, higher versatility, reproducibility, and suitability for automation (Ali et al., 2012a, 2015a; Fajardo et al., 2009a; Rahman et al., 2015). 


\subsubsection{Species-Specific PCR}

Species-specific PCR has been increasingly used because of its simplicity, high specificity, and high sensitivity; it is suitable for meat authentication studies even in complex and processed foods. It relies on accurate marker selection (Genbank, http://www. ncbi.nlm.nih.gov/) and design of specific primers that, after adequate method optimization, are able to produce one single PCR product from the target species. Speciesspecific PCR is mainly based on conventional PCR analyzed after 30-40 amplification cycles by agarose gel electrophoresis, known as qualitative or end-point PCR. Since amplification products are analyzed by the latter phases of amplification (plateau phase), the results are considered as qualitative, being quantitative or semiquantitative only in certain cases after cycle number optimization and normalization (Soares et al., 2010). Table 14.3 summarizes the wide number of species-specific PCR methods applied to meat species detection, which target mostly mtDNA markers as verified also in PCR-RFLP methods. A great advantage of species-specific PCR methods is the ability to provide results on relative and absolute sensitivity, contrary to most PCR-RFLP methods and other fingerprint techniques.

By the use of two or more specific primer pairs in the same PCR amplification and after adequate method optimization, we can easily advance to multitarget PCR. Multiplex end-point assays are very similar to single target PCR methods, with the great advantage of allowing simultaneous multitarget detection and becoming therefore cost-effective and high-throughput methods. Ali et al. (2014b) reported a comprehensive review on the multiplex PCR methods applied to species authentication, relating the important steps for method development. Table 14.3 also summarizes the reported multiplex PCR methods for meat species identification in foods.

\subsubsection{PCR-Sequencing}

Sequencing of PCR fragments allows collection of the full nucleotide information, which is then compared with a comprehensive reference database to achieve species identification. Ideally, the target DNA region must consist of a variable sequence that should be sufficiently informative for species differentiation. Additionally, the sequence should be flanked by highly conserved regions that are ideal for the design of universal PCR primers that amplify in a large number of species (Pereira et al., 2008). As for other PCR-based methods, mtDNA, such as cytochrome b, 12S, and 16S rRNA genes, have been widely used for species discrimination by PCRsequencing (Fajardo et al., 2010; Pereira et al., 2008). Regions with considerably high mutation ratios, such as most animal mtDNA sequences, are recommended to achieve discrimination of closely related species (Pereira et al., 2008). Currently, the mitochondrial gene coding for cytochrome c oxidase subunit I (COI) is considered a reliable DNA barcode for the discrimination of animal species.

PCR-sequencing targeting cytochrome $\mathrm{b}$ was used to detect goose species (Anser anser) in Italian "Mortara" salami (Colombo et al., 2002) and chamois (Rupicapra rupicapra) meat (Colombo et al., 2004). Horreo et al. (2013) designed universal primers based on the nucleotide sequences of the 16S rRNA gene of 40 animal species 
Table 14.3 Summarized Information About Methods of Species-Specific PCR Applied to Meat Species Detection

\begin{tabular}{|c|c|c|c|c|c|}
\hline Technique & Target species & Application & Target Gene & Sensitivity & References \\
\hline \multirow{9}{*}{$\begin{array}{l}\text { Species- } \\
\text { specific } \\
\text { PCR }\end{array}$} & Pork & $\begin{array}{l}\text { Raw meats, heat-treated } \\
\text { meats and sausages }\end{array}$ & $\begin{array}{l}\text { Porcine growth } \\
\text { hormone }\end{array}$ & $0.1 \%(\mathrm{w} / \mathrm{w})$ & Meyer et al. (1994) \\
\hline & $\begin{array}{l}\text { Goat, chicken, cattle, sheep, pig, and } \\
\text { horse }\end{array}$ & $\begin{array}{l}\text { Raw and heat-treated } \\
\text { meats }\end{array}$ & Cytochrome b & - & $\begin{array}{l}\text { Matsunaga et al. } \\
\text { (1999) }\end{array}$ \\
\hline & Cattle, pork, chicken, and ruminants & $\begin{array}{l}\text { Ground meats and } \\
\text { sausages }\end{array}$ & $\begin{array}{l}\text { Short interspersed } \\
\text { elements }\end{array}$ & $\begin{array}{l}0.5 \mathrm{pg} \text { (cattle DNA), } 0.05 \mathrm{pg} \\
\quad \text { (pork DNA), } 5 \mathrm{pg} \\
\text { (chicken DNA) } \\
0.005 \%(\mathrm{w} / \mathrm{w})(\text { cattle), } \\
0.0005 \%(\mathrm{w} / \mathrm{w})(\text { pork), } \\
0.05 \% \text { (chicken) }(\mathrm{w} / \mathrm{w})\end{array}$ & Walker et al. (2003) \\
\hline & Chicken, pork, goose, and mule duck & $\begin{array}{l}\text { Binary liver/foie gras } \\
\text { mixtures }\end{array}$ & $\alpha$-Actin & $0.1 \%(\mathrm{w} / \mathrm{w})$ & $\begin{array}{l}\text { Rodríguez et al. } \\
\text { (2003a) }\end{array}$ \\
\hline & $\begin{array}{l}\text { Chicken, pork, goose, turkey, and } \\
\text { mule duck }\end{array}$ & $\begin{array}{l}\text { Raw meats, livers, and } \\
\text { binary liver/foie gras } \\
\text { mixtures }\end{array}$ & $12 \mathrm{~S}$ rRNA & $1 \%(\mathrm{w} / \mathrm{w})$ & $\begin{array}{l}\text { Rodríguez et al. } \\
\text { (2003b) }\end{array}$ \\
\hline & Pork, cattle, sheep, and goat & $\begin{array}{l}\text { Raw and heat-treated } \\
\text { meat mixtures }\end{array}$ & $12 \mathrm{~S}$ rRNA & $1 \%(\mathrm{w} / \mathrm{w})$ & $\begin{array}{l}\text { Rodríguez et al. } \\
\text { (2004) }\end{array}$ \\
\hline & Cattle & $\begin{array}{l}\text { Raw meats, heat-treated } \\
\text { meats, beef in wheat } \\
\text { flour, tortellini, } \\
\text { sausages, and ravioli }\end{array}$ & Cytochrome b & $0.025 \%(\mathrm{w} / \mathrm{w})$ & $\begin{array}{l}\text { Pascoal et al. } \\
\text { (2005) }\end{array}$ \\
\hline & Cattle, sheep, goat, and deer & $\begin{array}{l}\text { Raw meats, heat-treated } \\
\text { meats, and meat } \\
\text { meals }\end{array}$ & $\begin{array}{l}\text { 12S rRNA- } \\
\text { tRNA }{ }^{\text {val }}-16 \mathrm{~S} \\
\text { rRNA }\end{array}$ & $0.05 \%(\mathrm{w} / \mathrm{w})$ & Ha et al. (2006) \\
\hline & $\begin{array}{l}\text { Horse, dog, cat, bovine, sheep, } \\
\text { porcine, and goat }\end{array}$ & $\begin{array}{l}\text { Binary raw meat } \\
\text { mixtures }\end{array}$ & Cytochrome b & $0.1 \%(\mathrm{w} / \mathrm{w})$ & $\begin{array}{l}\text { Ilhak and Arslan } \\
\text { (2007) }\end{array}$ \\
\hline
\end{tabular}




\begin{tabular}{|c|c|c|c|c|}
\hline Horse, donkey, and pork & $\begin{array}{l}\text { Binary raw meat } \\
\text { mixtures }\end{array}$ & $\begin{array}{l}\text { ATPase 8/ATPase 6, } \\
\text { ND2 and ND5 } \\
\text { (dehydrogenase } \\
\text { subunits } 2 \text { and 5) }\end{array}$ & $0.1 \%(w / w) 0.01 \mathrm{ng}$ DNA & $\begin{array}{l}\text { Kesmen et al. } \\
\text { (2007) }\end{array}$ \\
\hline Cattle, sheep, and goat & $\begin{array}{l}\text { Raw and heat-treated } \\
\text { meats }\end{array}$ & $12 \mathrm{~S}$ rRNA & $0.1 \%(w / w)$ & $\begin{array}{l}\text { Martín et al. } \\
\text { (2007a) }\end{array}$ \\
\hline $\begin{array}{l}\text { Muscovy duck, mallard duck, mule } \\
\text { duck, and common teal }\end{array}$ & $\begin{array}{l}\text { Raw meats, binary raw } \\
\text { meat mixtures, and } \\
\text { heat-treated meats }\end{array}$ & $12 \mathrm{~S}$ rRNA & $\begin{array}{l}0.1 \%(\mathrm{w} / \mathrm{w}) \text { (Muscovy duck } \\
\text { and mule duck in raw and } \\
\text { heat-treated meats) }\end{array}$ & $\begin{array}{l}\text { Martín et al. } \\
\text { (2007b) }\end{array}$ \\
\hline Red deer, fallow deer, and roe deer & $\begin{array}{l}\text { Raw and heat-treated } \\
\text { meats, hams, } \\
\text { sausages, and cooked } \\
\text { meats }\end{array}$ & 12S rRNA & - & $\begin{array}{l}\text { Fajardo et al. } \\
\qquad(2007 b)\end{array}$ \\
\hline Chamois, Pyrenean ibex, and mouflon & $\begin{array}{l}\text { Raw meats, binary raw } \\
\text { meat mixtures, and } \\
\text { heat-treated meats }\end{array}$ & D-loop & $0.1 \%(w / w)$ & $\begin{array}{l}\text { Fajardo et al. } \\
\qquad(2007 \mathrm{c})\end{array}$ \\
\hline Rabbit & $\begin{array}{l}\text { Binary raw and heat- } \\
\text { treated mixtures of } \\
\text { rabbit meat in oats }\end{array}$ & $12 \mathrm{~S}$ rRNA & $\begin{array}{l}0.1 \%(\mathrm{w} / \mathrm{w})(\text { raw and heat- } \\
\text { treated) }\end{array}$ & Martín et al. (2009) \\
\hline $\begin{array}{l}\text { Quail, pheasant, partridge, and guinea } \\
\text { fowl }\end{array}$ & $\begin{array}{l}\text { Binary raw meat } \\
\text { mixtures, pâtés, } \\
\text { braised meats, pickled } \\
\text { meats, and minced } \\
\text { meats }\end{array}$ & 12S rRNA & $\begin{array}{l}0.1 \%(\mathrm{w} / \mathrm{w})(\text { raw and heat- } \\
\text { treated) }\end{array}$ & Rojas et al. (2009b) \\
\hline $\begin{array}{l}\text { Turkey, chicken, duck, and guinea } \\
\text { fowl }\end{array}$ & Liquid and powder eggs & Cytochrome b & $0.1 \%(w / w)$ & Nau et al. (2009) \\
\hline Chicken, duck, pigeon, and pork & $\begin{array}{l}\text { Raw and heat-treated } \\
\text { meats, blood }\end{array}$ & $\begin{array}{l}\text { Cytochrome b, } \\
\text { D-loop }\end{array}$ & - & $\begin{array}{l}\text { Haunshi et al. } \\
\text { (2009) }\end{array}$ \\
\hline
\end{tabular}


Table 14.3 Summarized Information About Methods of Species-Specific PCR Applied to Meat Species Detection-cont'd

\begin{tabular}{|c|c|c|c|c|c|}
\hline Technique & Target species & Application & Target Gene & Sensitivity & References \\
\hline & Chicken & $\begin{array}{l}\text { Raw and heat-treated } \\
\text { meats, binary meat } \\
\text { mixtures (patty, } \\
\text { kebab, and block) }\end{array}$ & D-loop & $1 \%(\mathrm{w} / \mathrm{w})$ & Mane et al. (2009) \\
\hline & $\begin{array}{l}\text { Quail, pheasant, partridge and guinea } \\
\text { fowl, pigeon, Eurasian woodcock, } \\
\text { and song thrush }\end{array}$ & $\begin{array}{l}\text { Binary raw meat } \\
\text { mixtures }\end{array}$ & D-loop & $\begin{array}{l}0.1 \%(\mathrm{w} / \mathrm{w})(\mathrm{raw} \text { and heat- } \\
\quad \text { treated) }\end{array}$ & Rojas et al. (2010) \\
\hline & Chicken, turkey, and pork & $\begin{array}{l}\text { Raw meats, binary raw } \\
\text { meat mixtures, and } \\
\text { heat-treated meats }\end{array}$ & Cytochrome b & $0.1 \%(\mathrm{w} / \mathrm{w})$ (poultry) & $\begin{array}{l}\text { Hernández-Chávez } \\
\text { et al. (2011) }\end{array}$ \\
\hline & Cattle & $\begin{array}{l}\text { Raw and heat-treated } \\
\text { meats, binary meat } \\
\text { mixtures (patty, } \\
\text { kebab, and block) }\end{array}$ & D-loop & $<1 \%(\mathrm{w} / \mathrm{w})$ & Mane et al. (2012a) \\
\hline & Buffalo & $\begin{array}{l}\text { Raw and heat-treated } \\
\text { meats, binary meat } \\
\text { mixtures (patty, } \\
\text { kebab, and block) }\end{array}$ & D-loop & $1 \%(\mathrm{w} / \mathrm{w})$ & Mane et al. (2012b) \\
\hline & Hare & $\begin{array}{l}\text { Binary raw meat } \\
\text { mixtures }\end{array}$ & Cytochrome b & $0.01 \%(\mathrm{w} / \mathrm{w})$ & Santos et al. (2012) \\
\hline & Chicken & $\begin{array}{l}\text { Raw meats, blood, and } \\
\text { binary raw and heat- } \\
\text { treated meat mixtures }\end{array}$ & $\begin{array}{l}\text { 5-Aminolevulinate } \\
\text { synthase }\end{array}$ & $\begin{array}{l}0.1 \%(\mathrm{w} / \mathrm{w}) 10 \mathrm{pg} \text { (chicken } \\
\text { DNA) }\end{array}$ & $\begin{array}{r}\text { Karabasanavar } \\
\text { et al. (2013) }\end{array}$ \\
\hline & Pork & $\begin{array}{l}\text { Raw meats, blood, and } \\
\text { binary meats mixtures }\end{array}$ & D-loop & $\begin{array}{l}0.1 \%(\mathrm{w} / \mathrm{w}) 10 \mathrm{pg} \text { (pork } \\
\text { DNA) }\end{array}$ & $\begin{array}{r}\text { Karabasanavar } \\
\text { et al. (2014) }\end{array}$ \\
\hline
\end{tabular}




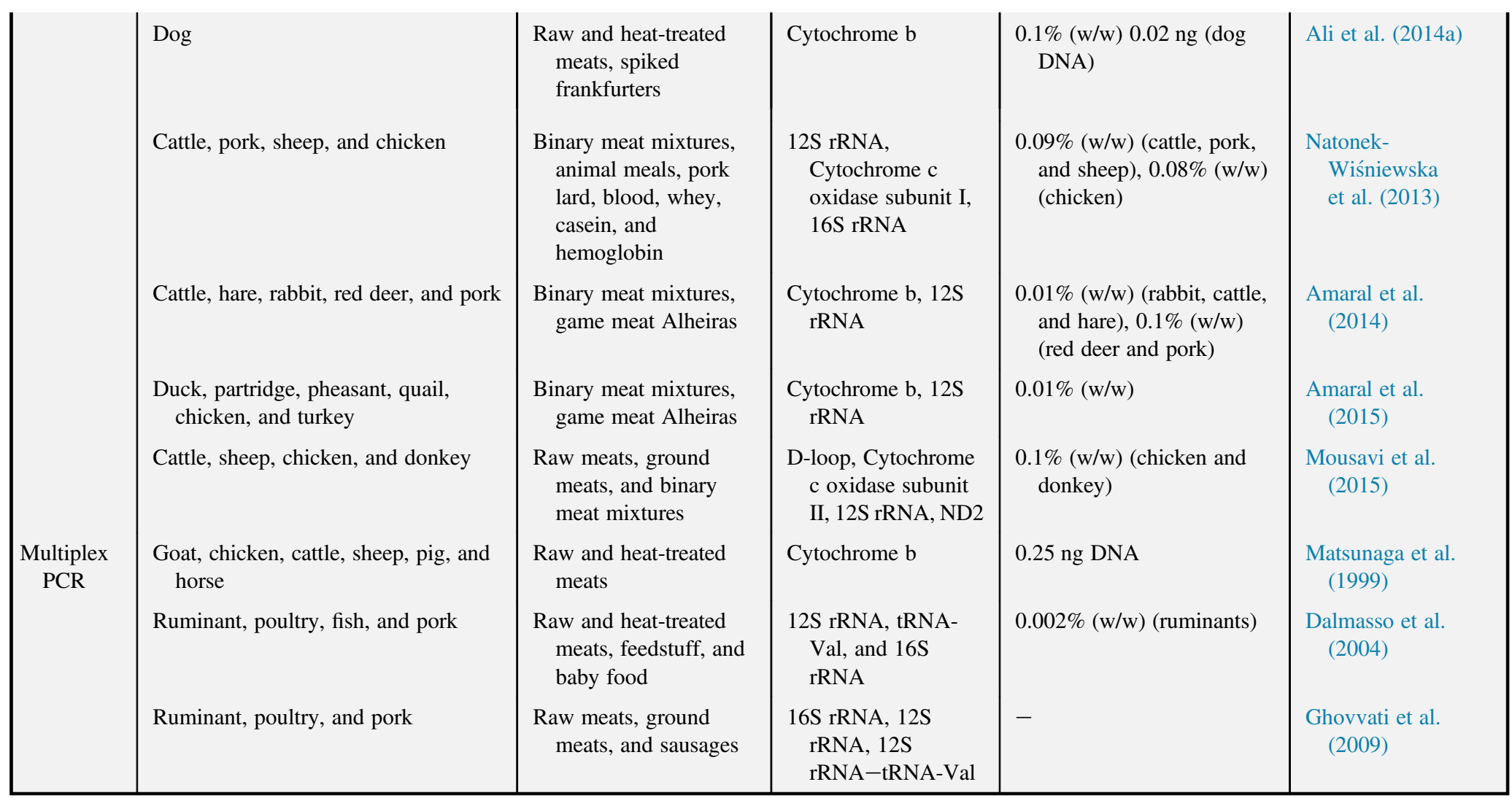


Table 14.3 Summarized Information About Methods of Species-Specific PCR Applied to Meat Species Detection-cont'd

\begin{tabular}{|c|c|c|c|c|c|}
\hline Technique & Target species & Application & Target Gene & Sensitivity & References \\
\hline & Pork and chicken & $\begin{array}{l}\text { Binary raw meat } \\
\text { mixtures }\end{array}$ & $\begin{array}{l}\text { Cytochrome b, 12S } \\
\text { rRNA }\end{array}$ & $\begin{array}{l}0.1 \%(\mathrm{w} / \mathrm{w}) \text { (pork detection) } \\
1 \%(\mathrm{w} / \mathrm{w}) \text { (pork } \\
\text { quantification) }\end{array}$ & Soares et al. (2010) \\
\hline & Cattle, sheep, pork, and poultry & $\begin{array}{l}\text { Blood and different } \\
\text { tissues }\end{array}$ & $\begin{array}{l}\text { tRNA-Val-16S } \\
\text { rRNA, tRNA-Lys- } \\
\text { ATPase } 8,12 \text { S } \\
\text { rRNA-tRNA-Val, } \\
\text { and 12S rRNA }\end{array}$ & $\begin{array}{c}1 \mathrm{ng} \text { (pork and sheep DNA), } \\
5 \mathrm{ng} \text { (poultry DNA), } \\
0.5 \mathrm{ng} \text { (cattle DNA) }\end{array}$ & Zha et al. (2010) \\
\hline & $\begin{array}{l}\text { Sika deer, wapiti, red deer, and } \\
\text { reindeer }\end{array}$ & Blood & D-loop, 16S rRNA & $\begin{array}{l}0.05 \mathrm{ng} \text { (sika deer and wapiti } \\
\text { DNA), } 0.1 \mathrm{ng} \text { (red deer } \\
\text { DNA), } 0.5 \mathrm{ng} \text { (red deer } \\
\text { DNA), } 0.02 \mathrm{ng} \text { (reindeer } \\
\text { DNA) }\end{array}$ & Zha et al. (2011) \\
\hline & Chicken, beef, pork, and mutton & $\begin{array}{l}\text { Half-cooked and cooked } \\
\text { meats, processed } \\
\text { foods }\end{array}$ & Cytochrome b & $1 \mathrm{ng}$ DNA & Zhang (2013) \\
\hline & Soybean, poultry, horse, and pork & Reference sausages & $\begin{array}{l}\text { Lectin, 12S rRNA, } \\
\text { Cytochrome b, } \\
\text { ATPase } 6\end{array}$ & $0.01 \%(\mathrm{w} / \mathrm{w})$ & Safdar et al. (2014) \\
\hline & $\begin{array}{l}\text { Cattle, chicken, goat, camel, and } \\
\text { donkey }\end{array}$ & Raw meats and sausages & $\begin{array}{l}\text { Cytochrome b, 12S } \\
\text { rRNA, ND2 }\end{array}$ & - & Nejad et al. (2014) \\
\hline
\end{tabular}




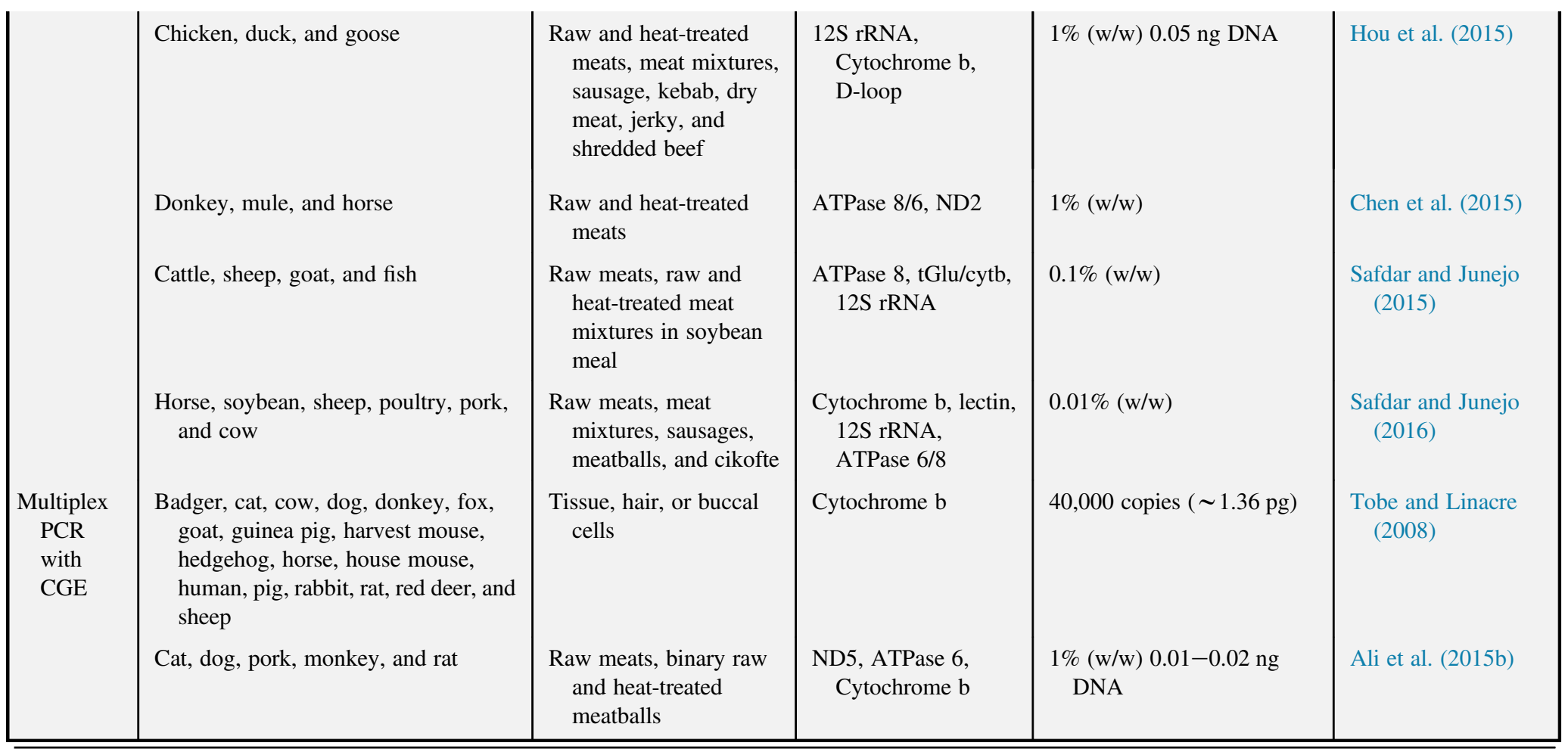

$C G E$, Capillary gel electrophoresis; $P C R$, polymerase chain reaction. 
that belonged to seven different taxonomic classes (Actinopterygii, Gasteropoda, Cephalaspidomorphi, Amphibia, Chondrichthyes, Aves, and Mammalia), obtaining PCR amplicons ranging from 80 to $125 \mathrm{bp}$. Sequencing analyses confirmed the differences among species and, although very short, they were considered very informative and enabled clustering of samples into their respective taxonomic group.

The mitochondrial 12S rRNA gene was first targeted by Girish et al. (2004) for the differentiation of cattle (Bos indicus), buffalo (Bubalus bubalis), sheep (Ovis aries), goat (Capra hircus), and mithun (Bos frontalis). The method was successfully applied to authenticate processed meat products (patties, steam cooked blocks, croquettes, and autoclaved blocks). Later on, the same authors used the same target gene and sequencing as a tool for further development of PCR-RFLP methods for meat species differentiation (Girish et al., 2005, 2007). In fact, sequencing of PCR products has been frequently used as an intermediate step during the development of several methods of PCR-RFLP (Fajardo et al., 2006; Rojas et al., 2009a), species-specific PCR (Haunshi et al., 2009; Santos et al., 2012), and real-time PCR (Laube et al., 2007; Santos et al., 2012; Kane and Hellberg, 2016).

The major limitation of PCR-sequencing is its unsuitability for identification of species in meat mixtures, producing ambiguous sequence results (Girish et al., 2004). The use of large sequence fragments is not recommended in the case of species identification in processed food products that contain low amounts of and degraded DNA (Pereira et al., 2008).

\subsubsection{DNA Barcoding}

DNA barcoding relies on sequence variation within a short and standardized region of the genome, designated as a "barcode," to provide accurate species identification. This approach is based on the analysis of the variability within a standard DNA barcode region, which is useful to establish taxonomic relationships. It involves the PCR amplification and sequencing of fragments of 400-800 bp by the use of consensus primers (Hebert et al., 2003). The Barcode of Life Data Systems (BOLD) is designed to support the generation and application of DNA barcode data, providing a data retrieval interface that enables searching public records by the use of multiple search criteria. An ideal DNA barcode should clearly enable a greater interspecies than intraspecies variability, allowing fast, reliable, automatable, and cost-effective species identification (Hebert et al., 2003). The COI barcoding region has been preferred among the mitochondrial protein-coding genes as the core molecular diagnostic system for animal species identification (Hebert et al., 2003; Luo et al., 2011).

The introduction of DNA barcoding represents a promising approach for food authentication, being broadly applied in fish species. DNA barcoding has been successful when applied to seafood because the number of species is high in comparison to other animal sources, such as cattle, sheep, goat, and horse, enhancing the effectiveness of the approach. Moreover, the classical identification methods are not useful in many cases, such as processed foods, and in the case of seafood, more than in other groups, it is possible to go further than the level of species identification (Galimberti et al., 2013). 
Although few applications have been published, DNA barcoding has emerged in recent years as a tool for the authentication of meats and meat products, including game. Quinto et al. (2016) performed a survey on game meat products sold in the United States in which the COI gene was successfully used as DNA barcoding to detect mislabeling. The same research group used the same DNA barcode approach to verify the labeling of ground meat products sold in the United States (Kane and Hellberg, 2016). In both studies, BOLD was used to identify sequences at the species level. In South Africa a DNA barcoding approach was effectively used to confirm that the reliability of commercial labeling of game meat is very poor (D'Amato et al., 2013) and for species identification in forensic wildlife cases (Dalton and Kotze, 2011). In spite of the advantages of DNA barcoding, currently it is not able to identify multiple species in meat mixtures, requiring the use of other methods, such as real-time PCR or next-generation sequencing (Hellberg and Morrissey, 2011; Kane and Hellberg, 2016). Another limitation is related to the use of relatively large fragment sizes ( $\sim 650 \mathrm{bp}$ ), which can disable the barcode amplification when analyzing highly processed foods containing degraded DNA (Fajardo et al., 2010).

\subsubsection{Real-Time PCR}

Real-time PCR is the method of choice in many laboratories for diagnostic tests and food analysis. It merges PCR chemistry with the use of fluorescent reporter molecules to monitor the PCR products along amplification cycles. The combination of high sensitivity and specificity, with reproducibility, low level of cross-contamination, and reduced time of analysis are advantages that make real-time PCR an attractive alternative to conventional PCR (Navarro et al., 2015). Probably the most important benefit of real-time PCR is its capacity to quantify the starting amount of a specific DNA target, which arises from its ability to measure the target product at early stages of amplification (exponential). To monitor the progress of amplification, different realtime PCR chemistries are available and classified into two main groups: doublestranded DNA intercalating molecules or binding dyes, such as SYBR green I and EvaGreen; and fluorophore-labeled oligonucleotides, such as the hydrolysis TaqMan probes (Navarro et al., 2015). The use of DNA binding dyes is the simplest and most economical approach because it does not need the use of any fluorophorelabeled oligonucleotides. However, it leads to specific and also to non-specific amplification products, requiring a melting curve analysis to verify specificity.

The most commonly used real-time PCR universal dye in several research areas, including meat species identification, is the SYBR green I (Ballin et al., 2009; Navarro et al., 2015). More recently, the use of third-generation dyes, such as EvaGreen, offers enhanced fluorescence since it can be used at higher concentrations than SYBR green I, generating greater signals, increased sensitivity, and excellent stability without causing PCR inhibition (Wang et al., 2006). The application of real-time PCR with EvaGreen fluorescent dye has been reported in the identification of Cervidae (Chen et al., 2009) and hare meat species (Santos et al., 2012). The use of EvaGreen, as a saturation dye, offers also the advantage of performing high-resolution melting (HRM) analysis, when using high-resolution instrumentation. HRM analysis involves 
a more precise temperature control when performing melting curve analysis and an enhanced data acquisition system as compared to current equipment. HRM analysis has already demonstrated its potential in food analysis, particularly in differentiating closely related species and plant cultivars (Druml and Cichna, 2014). In pork meat traceability, HRM analysis targeting SNP detection was successfully applied as a genotyping method (Yang et al., 2014). The report showed that results of HRM genotyping were accurate and, in general, consistent with PCR-RFLP and real-time PCR with TaqMan probes data, but at a much lower cost.

The real-time PCR approach with hydrolysis TaqMan probes has been widely applied to several areas of research (Navarro et al., 2015), as the most common being in food authentication, genetically modified organism quantification, and allergen detection (Ali et al., 2014b; Ballin et al., 2009; Costa et al., 2016b; Mafra et al., 2008). Hydrolysis probes are designed to bind to a specific region of the target DNA, with mechanism of action that relies on the 5-3' exonuclease activity of Taq polymerase, which degrades the bound probe during amplification. TaqMan probes contain a donor fluorescent moiety at the $5^{\prime}$-end and an acceptor fluorescent moiety at the $3^{\prime}$-end that quenches the fluorescence emitted from the donor molecule because of their close proximity. Advantages of using TaqMan probes are related to their relatively simple design and multiplexing capacity, without requiring melting curve analysis (Navarro et al., 2015). Table 14.4 summarizes the reported real-time PCR methods for meat species identification in foods, in which can be seen the extensive use of TaqMan probes, targeting mostly mtDNA.

\subsubsection{Next-Generation Sequencing}

In recent years, enormous progress has been made in DNA sequencing technologies. Next-generation sequencing (NGS) technologies have revolutionized the analysis of DNA, in terms of speed, read length, and throughput, along with a sharp reduction in cost per-base. Compared to first-generation sequencing methods, such as Sanger sequencing, the new methods share three major improvements: (1) they rely on the preparation of NGS libraries in a cell-free system, without requiring bacterial cloning of DNA fragments; (2) they produce thousands to several millions of sequencing reactions in parallel, instead of hundreds; and (3) the sequencing output is directly detected without the need for postreaction analysis, such electrophoresis, and the nucleotide base query is performed cyclically and in parallel (van Dijk et al., 2014; Fig. 14.2). NGS is becoming a standard approach in a large number of studies in all species and in many different fields, including resequencing or de novo sequencing of large and small genomes, metagenomics, and transcriptomics among many other research and applied areas (Bertolini et al., 2015; Buermans and den Dunnen, 2014; van Dijk et al., 2014). The huge number of reads generated by NGS has enabled the sequencing of entire genomes with exceptional speed. This has become possible in part because of significant advances in data handling by bioinformatic tools.

Despite the high potential of NGS for species identification, only a few studies have been reported regarding meat species differentiation. Tillmar et al. (2013) described a DNA-typing method for the determination of mammal species using targeted, 
Table 14.4 Summarized Information About Methods of Real-Time PCR Applied to Meat Species Detection

\begin{tabular}{|c|c|c|c|c|c|}
\hline Technique & Target Species & Application & Target Gene & Sensitivity & References \\
\hline \multirow[t]{7}{*}{$\begin{array}{l}\text { Real-time PCR } \\
\text { with TaqMan } \\
\text { probes }\end{array}$} & $\begin{array}{l}\text { Cattle, pork, } \\
\text { lamb, } \\
\text { chicken, and } \\
\text { turkey }\end{array}$ & Binary raw meat mixtures & Cytochrome b & $0.5 \%(w / w)$ & $\begin{array}{l}\text { Dooley et al. } \\
\text { (2004) }\end{array}$ \\
\hline & $\begin{array}{r}\text { Horse and } \\
\text { donkey }\end{array}$ & $\begin{array}{l}\text { Model raw meat mixtures and } \\
\text { commercial products (horse } \\
\text { sausage, horse steak, horse burger, } \\
\text { horse ham, and horse salami) }\end{array}$ & Cytochrome b & $\begin{array}{l}1 \mathrm{pg} \text { (donkey DNA) or } \\
25 \text { pg (horse DNA) }\end{array}$ & $\begin{array}{l}\text { Chisholm et al. } \\
\text { (2005) }\end{array}$ \\
\hline & $\begin{array}{l}\text { Duck (mallard } \\
\text { and Muscovy } \\
\text { duck) }\end{array}$ & $\begin{array}{l}\text { Roasted duck, smoked duck, duck } \\
\text { pâté, game casserole, and feed } \\
\text { samples }\end{array}$ & Cytochrome b & $\begin{array}{l}\text { Estimated as } 0.0001 \% \\
\qquad(\mathrm{w} / \mathrm{w})\end{array}$ & Hird et al. (2005) \\
\hline & Pork & $\begin{array}{l}\text { Binary mixtures of raw and sterilized } \\
\text { pork in beef muscles }\end{array}$ & 12S rRNA & $\begin{array}{l}0.01 \mathrm{ng} \text { (pork DNA), } 0.5 \% \\
(\mathrm{w} / \mathrm{w}) \text { (pork in beef } \\
\text { mixtures) }\end{array}$ & $\begin{array}{l}\text { Rodríguez et al. } \\
\text { (2005) }\end{array}$ \\
\hline & $\begin{array}{l}\text { Cattle, pork, } \\
\text { lamb, goat, } \\
\text { chicken, } \\
\text { turkey, and } \\
\text { duck }\end{array}$ & $\begin{array}{l}\text { Home canned food, normal cans, cans } \\
\text { for use under tropical conditions, } \\
\text { and ultra-high heat-treated cans } \\
\text { with an amount of at least } 0.1 \% \text { of } \\
\text { the respective species }\end{array}$ & $\begin{array}{l}\text { Cyclic guanosine } \\
\text { monophosphate } \\
\text { phosphodiesterase, } \\
\text { ryanodine receptor, } \\
\text { and interleukin-2 } \\
\text { precursor }\end{array}$ & 10 genome copies & $\begin{array}{l}\text { Laube et al. } \\
\text { (2007) }\end{array}$ \\
\hline & Cattle & $\begin{array}{l}\text { Raw meats, processed meat products, } \\
\text { milk, and cheese }\end{array}$ & Cytochrome b & 35 pg (cattle DNA) & $\begin{array}{l}\text { Zhang et al. } \\
\text { (2007) }\end{array}$ \\
\hline & $\begin{array}{l}\text { Cattle, pork, } \\
\text { horse, } \\
\text { mutton, } \\
\text { chicken, and } \\
\text { turkey }\end{array}$ & Processed meat products & $\begin{array}{l}\text { Satellite IV DNA for } \\
\text { cattle and } \\
\text { cytochrome b for the } \\
\text { other species }\end{array}$ & $\begin{array}{l}0.05 \%(\mathrm{w} / \mathrm{w}) \text { (pork, lard, } \\
\text { horse, mutton, chicken, } \\
\text { and turkey), } 0.1 \% \text { (cattle) }\end{array}$ & $\begin{array}{l}\text { Jonker et al. } \\
\quad(2008)\end{array}$ \\
\hline
\end{tabular}


Table 14.4 Summarized Information About Methods of Real-Time PCR Applied to Meat Species

\section{Detection-cont'd}

\begin{tabular}{|c|c|c|c|c|c|}
\hline Technique & Target Species & Application & Target Gene & Sensitivity & References \\
\hline & $\begin{array}{l}\text { Chamois and } \\
\text { Pyrenean ibex }\end{array}$ & Raw and heat-treated binary mixtures & 12S rRNA and D-loop & - & $\begin{array}{l}\text { Fajardo et al. } \\
\qquad(2009 a, b)\end{array}$ \\
\hline & $\begin{array}{l}\text { Donkey, pork, } \\
\text { and horse }\end{array}$ & $\begin{array}{l}\text { Raw and cocked patty samples } \\
\text { prepared with binary meat } \\
\text { mixtures in beef }\end{array}$ & $\begin{array}{l}\text { Mitochondrial ND2, } \\
\text { ND5, and ATPase } \\
6 / 8\end{array}$ & $\begin{array}{l}0.0001 \%(\mathrm{w} / \mathrm{w}) 0.0001 \mathrm{ng} \\
\text { DNA }\end{array}$ & $\begin{array}{l}\text { Kesmen et al. } \\
\text { (2009) }\end{array}$ \\
\hline & Pork & $\begin{array}{l}\text { Model meatballs spiked with pork } \\
\text { meat, commercial meatballs of } \\
\text { pork, beef, chicken, mutton, and } \\
\text { chevon/goat }\end{array}$ & Cytochrome b & $0.01 \%(w / w)$ & Ali et al. (2012b) \\
\hline & Pork & $\begin{array}{l}\text { Model chicken nuggets spiked with } \\
\text { pork meat, commercial nuggets of } \\
\text { pork, beef, chicken, mutton, and } \\
\text { chevon }\end{array}$ & Cytochrome b & $0.01 \%(\mathrm{w} / \mathrm{w})$ & Ali et al. (2012c) \\
\hline & Rabbit and hare & $\begin{array}{l}\text { Binary mixtures of processed } \\
\text { muscles [rabbit, hare, and rabbit } \\
\text { plus hare }(1: 1, w / w)] \text { in oat } \\
\text { matrix; commercial dog and cat } \\
\text { foods labeled as containing rabbit }\end{array}$ & $12 \mathrm{~S}$ rRNA & $\begin{array}{c}0.1 \%(\mathrm{w} / \mathrm{w})(\text { processed } \\
\text { muscles), } 0.01 \mathrm{ng} / \mu \mathrm{L} \\
\text { (each target DNA) }\end{array}$ & $\begin{array}{l}\text { Pegels et al. } \\
\text { (2013) }\end{array}$ \\
\hline & $\begin{array}{l}\text { Fallow deer, red } \\
\text { deer, and sika } \\
\text { deer }\end{array}$ & $\begin{array}{l}\text { Meat products labeled as containing } \\
\text { deer or game, model game sausage }\end{array}$ & $\begin{array}{l}\text { Epidermal growth factor } \\
\text { pseudogene }\end{array}$ & $\begin{array}{l}0.5 \%(\mathrm{w} / \mathrm{w})(\text { fallow deer and } \\
\quad \text { red deer }), 0.1 \%(\mathrm{w} / \mathrm{w}) \\
\quad(\text { sika deer })\end{array}$ & $\begin{array}{l}\text { Druml et al. } \\
\qquad(2015 \mathrm{a})\end{array}$ \\
\hline & Roe deer & $\begin{array}{l}\text { Raw binary meat mixtures with pork, } \\
\text { game model sausage }\end{array}$ & Lactoferrin & $0.03 \%(w / w)$ & $\begin{array}{l}\text { Druml et al. } \\
\qquad(2015 \mathrm{c})\end{array}$ \\
\hline & Cat and dog & $\begin{array}{l}\text { Samples of pet food, farm animal } \\
\text { products, and raw materials }\end{array}$ & $\begin{array}{l}\text { Cytochrome oxidase } \\
\text { subunit I }\end{array}$ & $\begin{array}{l}2 \text { pg (cat DNA), } 0.2 \mathrm{pg}(\mathrm{dog} \\
\text { DNA) }\end{array}$ & $\begin{array}{l}\text { Espiñeira and } \\
\text { Vieites } \\
(2015)\end{array}$ \\
\hline & Horse & $\begin{array}{l}\text { Heat-processed binary mixtures of } \\
\text { horse in bovine meat, meat-based } \\
\text { products, and pet foods }\end{array}$ & $12 \mathrm{~S}$ rRNA & 1 pg horse DNA & $\begin{array}{l}\text { Pegels et al. } \\
\qquad(2015)\end{array}$ \\
\hline
\end{tabular}




\begin{tabular}{|c|c|c|c|c|c|}
\hline & Horse & $\begin{array}{l}\text { Raw binary mixtures of horse meat in } \\
\text { beef }\end{array}$ & $\begin{array}{l}\text { Equine growth hormone } \\
\text { receptor }\end{array}$ & $\leq 0.1 \%(w / w)$ & $\begin{array}{l}\text { Nixon et al. } \\
\quad(2015)\end{array}$ \\
\hline & Camel & Braised camel meat and charqui & Cytochrome b & $\begin{array}{l}0.01 \%(\mathrm{w} / \mathrm{w}) 5 \mathrm{fg} / \mu \mathrm{L} \text { camel } \\
\text { DNA }\end{array}$ & Wu et al. (2015) \\
\hline & Dog & $\begin{array}{l}\text { Model chicken nuggets with known } \\
\text { amounts of dog meat, halal } \\
\text { commercial chicken nuggets }\end{array}$ & Cytochrome b & $0.01 \%(w / w)$ & $\begin{array}{l}\text { Rahman et al. } \\
\text { (2016) }\end{array}$ \\
\hline \multirow[t]{5}{*}{$\begin{array}{l}\text { Multiplex real- } \\
\text { time PCR with } \\
\text { TaqMan probes }\end{array}$} & $\begin{array}{l}\text { Chicken, duck, } \\
\text { and pork }\end{array}$ & $\begin{array}{l}\text { Ternary mixtures of pork, duck, and } \\
\text { goose blood }\end{array}$ & $\begin{array}{l}\text { Beta-actin, transforming } \\
\text { growth factor, T-cell } \\
\text { growth factor }\end{array}$ & $\begin{array}{l}1 \%(\mathrm{w} / \mathrm{w}) \text { (three target } \\
\text { species in ternary } \\
\text { mixtures), } 0.15 \mathrm{ng} \text { for all } \\
\text { species }\end{array}$ & $\begin{array}{l}\text { Cheng et al. } \\
\text { (2014) }\end{array}$ \\
\hline & $\begin{array}{l}\text { Roe deer and } \\
\text { deer (the sum } \\
\text { of fallow } \\
\text { deer, red deer, } \\
\text { and sika deer) }\end{array}$ & $\begin{array}{l}\text { Raw binary meat mixtures with pork, } \\
\text { several meat species mixtures, } \\
\text { model game sausage }\end{array}$ & $\begin{array}{l}\text { Lactoferrin, exon } 21 \text { of } \\
\text { epidermal growth } \\
\text { factor pseudogene }\end{array}$ & - & $\begin{array}{l}\text { Druml et al. } \\
\quad(2015 b)\end{array}$ \\
\hline & Cattle and pork & $\begin{array}{l}\text { Raw binary meat mixtures, minced } \\
\text { meat products, and meat products }\end{array}$ & $\begin{array}{l}\text { Cyclic-guanosine } \\
\text { monophosphate } \\
\text {-phosphodiesterase, } \\
\beta \text {-actin }\end{array}$ & 20 genome equivalents & $\begin{array}{l}\text { Iwobi et al. } \\
\text { (2015) }\end{array}$ \\
\hline & $\begin{array}{l}\text { Murine (lab rat, } \\
\text { lab mouse, } \\
\text { and wild } \\
\text { mouse) }\end{array}$ & $\begin{array}{l}\text { Binary meat mixture of murine meat } \\
\text { in mutton, meat products spiked } \\
\text { with murine meat }\end{array}$ & Cytochrome b & $\begin{array}{l}0.1 \%(\mathrm{w} / \mathrm{w}), 1 \mathrm{pg} \text { of DNA } \\
\text { per reaction }\end{array}$ & $\begin{array}{l}\text { Fang and Zhang } \\
\text { (2016) }\end{array}$ \\
\hline & $\begin{array}{l}\text { Duck, goose, } \\
\text { chicken, } \\
\text { turkey, and } \\
\text { pork }\end{array}$ & $\begin{array}{l}\text { Model liver pâté (containing goose, } \\
\text { duck, and chicken liver and turkey } \\
\text { and pork meat), liver-meat } \\
\text { products }\end{array}$ & Cytochrome b, D-loop & $\begin{array}{l}2 \%(\mathrm{w} / \mathrm{w})(\text { turkey), } 1 \% \\
\quad(\mathrm{w} / \mathrm{w})(\text { duck, goose, and } \\
\text { chicken), } 1 \%(\mathrm{w} / \mathrm{w}) \text { (pork) }\end{array}$ & $\begin{array}{l}\text { Köppel et al. } \\
\text { (2013) }\end{array}$ \\
\hline
\end{tabular}


Table 14.4 Summarized Information About Methods of Real-Time PCR Applied to Meat Species

\section{Detection-cont'd}

\begin{tabular}{|c|c|c|c|c|c|}
\hline Technique & Target Species & Application & Target Gene & Sensitivity & References \\
\hline $\begin{array}{l}\text { Real-time PCR } \\
\text { with TaqMan } \\
\text { minor groove } \\
\text { binding probes }\end{array}$ & Cattle and pork & $\begin{array}{l}\text { Raw and cooked/sterilized meatballs } \\
\text { prepared with binary mixtures of } \\
\text { beef and pork }\end{array}$ & t-Glu-cytb & $\begin{array}{l}1 \%(\mathrm{w} / \mathrm{w})(\text { raw and cooked/ } \\
\text { sterilized beef }), 1 \%(\mathrm{w} / \mathrm{w}) \\
(\text { raw pork }), 5 \%(\mathrm{w} / \mathrm{w}) \\
(\text { cooked/sterilized pork) }\end{array}$ & $\begin{array}{l}\text { López-Andreo } \\
\text { et al. (2012) }\end{array}$ \\
\hline $\begin{array}{l}\text { Real-time PCR } \\
\text { with molecular } \\
\text { beacon probe }\end{array}$ & Pork & Raw meat mixtures & Cytochrome b & $\begin{array}{l}0.1 \%(\mathrm{w} / \mathrm{w}) \text { (pork in } \\
\text { pork-beef mixtures), } \\
0.0001 \mathrm{ng} \text { pork DNA }\end{array}$ & $\begin{array}{l}\text { Yusop et al. } \\
\text { (2012) }\end{array}$ \\
\hline \multirow{2}{*}{$\begin{array}{l}\text { Real-time PCR } \\
\text { with TaqMan } \\
\text { probes and real- } \\
\text { time with } \\
\text { SYBR green I } \\
\text { dye }\end{array}$} & Capercaillie & $\begin{array}{l}\text { Raw and sterilized binary mixtures of } \\
\text { capercaillie in chicken meat }\end{array}$ & $12 \mathrm{~S}$ rRNA & $0.1 \%(\mathrm{w} / \mathrm{w})$ & $\begin{array}{l}\text { Rojas et al. } \\
\text { (2011) }\end{array}$ \\
\hline & $\begin{array}{c}\text { Cattle and } \\
\text { buffalo }\end{array}$ & Milk- and meat-derived food products & $\begin{array}{l}\text { Cytochrome b, } 16 \mathrm{~S} \\
\text { rRNA }\end{array}$ & - & $\begin{array}{l}\text { Drummond et al. } \\
\qquad(2013)\end{array}$ \\
\hline \multirow[t]{2}{*}{$\begin{array}{l}\text { Real-time PCR } \\
\text { with SYBR } \\
\text { green I dye }\end{array}$} & Pork & $\begin{array}{l}\text { Different mixtures of pork, cattle, } \\
\text { camel, horse, and chicken raw } \\
\text { meats, halal-labeled beef, and } \\
\text { chicken products }\end{array}$ & Mitochondrial DNA & $0.1 \mathrm{ng}$ (pork DNA) & $\begin{array}{l}\text { Farrokhi and } \\
\text { Joozani } \\
\text { (2011) }\end{array}$ \\
\hline & Pork & $\begin{array}{l}\text { Raw binary mixtures in poultry meat, } \\
\text { frankfurters, barbecue sausages, } \\
\text { hamburgers, and nuggets }\end{array}$ & Cytochrome b & $0.1 \%(\mathrm{w} / \mathrm{w}) 5 \mathrm{pg}$ (pork DNA) & $\begin{array}{l}\text { Soares et al. } \\
\quad(2013)\end{array}$ \\
\hline $\begin{array}{l}\text { Real-time PCR } \\
\text { with EvaGreen } \\
\text { dye }\end{array}$ & Hare & Binary raw meat mixtures & Cytochrome b & 1 pg (hare DNA) & $\begin{array}{l}\text { Santos et al. } \\
\quad(2012)\end{array}$ \\
\hline $\begin{array}{l}\text { Multiplex real- } \\
\text { time PCR with } \\
\text { EvaGreen dye }\end{array}$ & $\begin{array}{l}\text { Cattle and } \\
\text { soybean }\end{array}$ & $\begin{array}{l}\text { Model sausages and commercial } \\
\text { sausages }\end{array}$ & ATPase 8 , lectin & $\begin{array}{l}0.003 \%(\mathrm{w} / \mathrm{w})(\mathrm{beef}) \\
0.001 \%(\mathrm{w} / \mathrm{w}) \text { (soybean) }\end{array}$ & $\begin{array}{l}\text { Safdar and } \\
\text { Abasıyanık } \\
\text { (2013) }\end{array}$ \\
\hline
\end{tabular}


(A) Fragmentation

Adapter addition
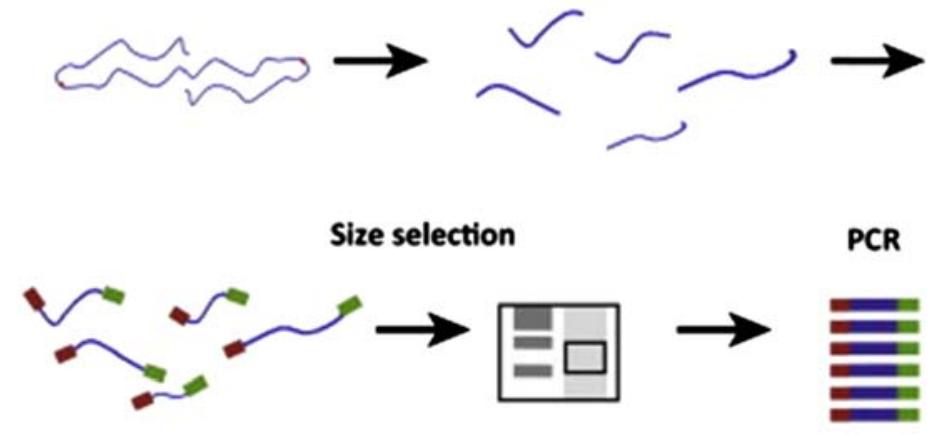

(B)

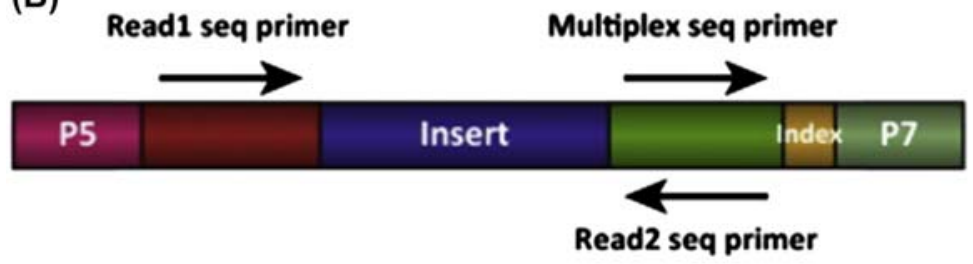

$\overline{\text { TRENDS in Genetics }}$

Figure 14.2 (A) Simplified representation of a typical next-generation sequencing (NGS) library preparation workflow. (B) Architecture of a standard Illumina NGS library. Adapters are indicated in two-tone red and green, the insert is in blue. An index or barcode is indicated in yellow. Sequencing primers are indicated by arrows. Shown is an Illumina library in which "P5" and "P7" are the sequences used for flow cell attachment and amplification. In other technologies the names of these terminal sequences are different, but the principle is the same. Reprinted with permission from van Dijk, E.L., Auger, H., Jaszczyszyn, Y., Thermes, C., 2014. Ten years of next-generation sequencing technology. Trends in Genetics (30), 418-426. Copyright () 2014 Elsevier.

massively parallel sequencing of a short mtDNA sequence by means of NGS. The method was designed through phylogenetic analyses of DNA reference sequences of more than 300 mammal species, using binary DNA mixtures. Results obtained were promising since they allowed discrimination of over $99.9 \%$ of mammal species, with the ability to detect minor components at concentrations as low as $1 \%(\mathrm{w} / \mathrm{w})$ in mixed samples (Tillmar et al., 2013). A major advantage of NGS cited by the authors was the use of short PCR amplicons, which facilitates the analysis of degraded and poor-quality DNA. The use of universal PCR primers, without requiring prior species or sequence information and the possibility of detecting minute amounts of DNA, is an additional advantage of NGS, particularly in the case of forensic and food analysis.

The report of Ripp et al. (2014) showed that NGS of total DNA derived from foodstuff material can readily identify and quantify species components with high accuracy by a single experimental assay. Sequence data simulation and real-case Illumina sequencing of DNA from reference sausages composed of mammalian (pig, cow, 
horse, sheep) and avian (chicken, turkey) species were able to correctly quantify material at the $1 \%(\mathrm{w} / \mathrm{w})$ level via a read counting approach. The same authors performed an additional metagenomic step to facilitate identification of traces from animal, plant, and microbial DNA, including unexpected species, which is prospectively important for the detection of food allergens and pathogens.

In the report by Bertoloni et al. (2015), the potential of the next-generation semiconductor-based sequencing technology (Ion Torrent Personal Genome Machine) was evaluated for the identification of DNA from meat species (pig, horse, cattle, sheep, rabbit, chicken, turkey, pheasant, duck, goose, and pigeon), as well as from human and rat, in DNA mixtures, using different universal primers to target the mitochondrial $12 \mathrm{~S}$ and $16 \mathrm{~S}$ rRNA genes. The approach allowed the detection of low levels of pork and horse DNA from reads obtained with different universal primer pairs, which could overcome the potential problems of amplification competition among species.

\subsubsection{Biosensors}

Recently, DNA biosensors and DNA biochip technology have been suggested as high-throughput alternative genetic approaches. Ali et al. (2011) developed a novel nanobiosensor based on a $3 \mathrm{~nm}$ diameter citrate-tannate-coated gold nanoparticle functionalized with a fluorophore-labeled probe consisting of a 27-nucleotide $A l u \mathrm{I}$-fragment of pork cytochrome $\mathrm{b}$ gene. This biosensor was able to detect $0.5 \%$ and $1 \%(\mathrm{w} / \mathrm{w})$ of pork in, respectively, raw and autoclaved beef binary meat mixtures, in a single step without any separation or washing. Considering that the degree of fluorescence depends on the degree of target binding, the method has the potential for quantitation by the use of a standard curve generated with known concentrations of probes and targets (Ali et al., 2011). The same methodology was further applied for the quantitative estimation of spiked pork in burger formulations (Ali et al., 2012d) and in mixed meatball preparations (Ali et al., 2014c), both with more than 90\% accuracy.

DNA biochips rely on the use of microarray analysis and exploit the principle of hybridization of PCR-amplified fragments on specific probes bound onto the arrays. The technique presents, in general, the major advantage of allowing for simultaneous detection of multiple targets, saving time and reducing costs, but it can be limited by the overall proficiency of the PCR amplification (Iwobi et al., 2011). Iwobi et al. (2011) tested and compared two commercially available animal DNA biochip detection systems, the CarnoCheck Test Kit (Greiner Bio-One) and the MEAT ${ }^{\text {species }}$ LCD Array (Chipron), which allow the simultaneous identification of 8 and 14 animal species, respectively (Fig. 14.3). Both test systems are based on the PCR amplification of consensus DNA regions and species-specific probes that exploit differences within the mtDNA of the targeted animal species. The two systems showed a good sensitivity, although this was higher for the LCD array since at least $0.1 \%$ of all meat species in the analyzed samples were detectable using this biochip. The two systems were applied to the analysis of 70 commercial samples and the results validated against conventional PCR methods, showing a general good performance of both DNA biochips. A possible disadvantage of the method, in particular for the CarnoCheck Test Kit, is 


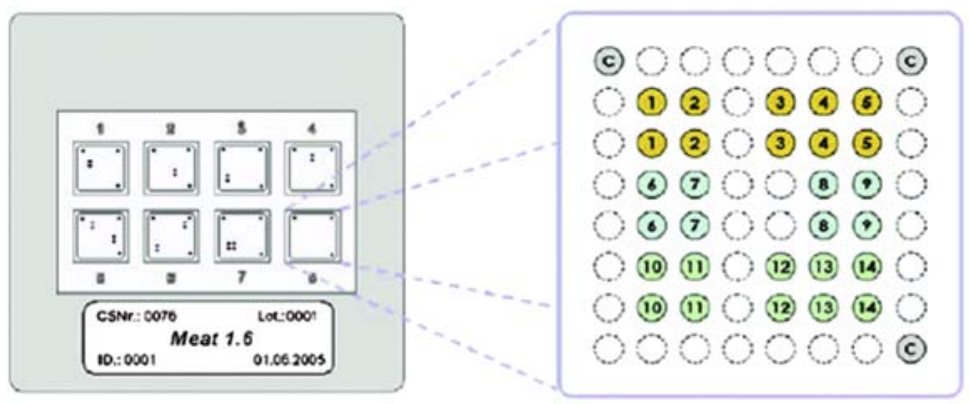

\section{Capture Probes}

\begin{tabular}{|l|l|l|l|l|l|}
\hline $\mathrm{N}^{\circ}$ & Probe & \multicolumn{1}{|c|}{ Specificity } & $\mathrm{N}^{\circ}$ & \multicolumn{1}{|c|}{ Probe } & Specificity \\
\hline 01 & Beef & Bos taurus & 08 & Rabbit & Oryctolagus cuniculus \\
\hline 02 & Buffalo & Bubalus bubalis & 09 & Hare & Lepus europaeus \\
\hline 03 & Pork & Sus scrofa & 10 & Chicken & Gallus gallus \\
\hline 04 & Sheep & Ovis aries & 11 & Turkey & Meleagris gallopavo \\
\hline 05 & Goat & Capra hircus & 12 & Goose & Ansa albifrons \\
\hline 06 & Horse & Equus caballus 1) & 13 & Mall. Duck & Anas platyrhyncos \\
\hline 07 & Donkey & Equus a sinus 1) & 14 & Musc. Duck & Cairina moschata \\
\hline & & & C & Hyb-Contr. & Functional controls (Hybridization + stain) \\
\hline
\end{tabular}

Figure 14.3 LCD Array Meat 1.6 Test System for meat species identification. The figure shows the spotting pattern of the array while the table lists the capture probes immobilized on each array (Data Sheet MeatSpecies 1.6, V-I-08, Chipron).

Reprinted with permission from Iwobi, A.N., Huber, I., Hauner, G., Miller, A., Busch, U., 2011. Biochip technology for the detection of animal species in meat products. Food Analytical Methods (4), 389-398. Copyright () 2010 Springer Science + Business Media, LLC.

the need for a special scanner and software to analyze results. As a result, a siliconbased optical thin-film biosensor DNA chip was developed for the identification of eight animal species, for which color change results could be interpreted by the naked eye without the need for expensive instruments (Wang et al., 2015).

\subsection{Spectroscopic Methods}

In recent years, several studies have focused on the possibility of using spectroscopy for meat authentication purposes for several reasons including speed and its nondestructive character, being able to obtain information about the chemical structure of molecules without causing sample alteration. Its simplicity, both in regard to sample preparation and the possibility of being operated by nonexpert technicians, is another advantage. However, an essential point for the successful application of spectroscopy relies on the construction of a suitable spectral database, which should include, ideally, all the possible parameter variations likely to be found in the matrices under evaluation. Based on such databases, useful models can be created, tested, and validated through the use of appropriate multivariate statistical tools. To date, different 
techniques have been applied to meat authentication studies, including Raman, Fourier-transform infrared (FTIR), near-infrared (NIR), and mid-infrared (MIR) spectroscopy, among others. However, most studies performed so far only comprise the evaluation of raw meats and include, generally, a low number of samples to build up the proposed models. Moreover, several aimed only at differentiating singlespecies meats, without evaluating the possibility of meat mixtures.

The use of FTIR spectroscopy and partial least square (PLS) calibration was proposed by Rohman et al. (2011) to detect beef meatball adulteration with pork meat. Fat extracted from beef meatball adulterated with $1.0-100.0 \%(\mathrm{w} / \mathrm{w})$ of pork was analyzed by FTIR spectroscopy in the MIR region $\left(4000-650 \mathrm{~cm}^{-1}\right)$ for quantification purposes. Statistical results, calculated from the prediction samples set as mean difference and standard deviation of difference for determination of accuracy (closeness of agreement between actual data and the predicted data of FTIR results) and precision (measure of the random error in a dataset), indicated that the methodology was appropriate and precise enough to detect adulteration with pork meat. However, the authors stated that beef and pork samples were randomly obtained from five different slaughter houses and that the calibration set comprised pork spiked at concentrations of $1 \%, 3 \%, 5 \%, 10 \%$, and $25 \%(\mathrm{w} / \mathrm{w})$, but the total number of analyzed samples was not specified. Moreover, instead of using an independent validation dataset, the calibration model was cross-validated using the "leave-one-out" technique by removing one sample spectrum at a time. The same technique was later used by the same research group to detect adulteration of beef meatballs with rat meat (Rahmania et al., 2015). In this work, besides PLS calibration, principal component analysis (PCA) was used, resulting in a clear separation of $100 \%$ beef and $100 \%$ rat meatballs. For the four commercial samples analyzed in the study, two presented score plots closer to beef meatballs, being classified as beef samples, but PCA analysis failed to classify the other two because they were far away from pure meat samples. Thus, more work is needed to clarify these results, possibly comprising the use of a larger dataset, including also binary meat mixtures.

Raman spectroscopy, combined with chemometrics, has been suggested by Boyac1 et al. (2014) for the discrimination of beef and horse meat. Raman spectra were obtained from fat extracted from different parts of horse and beef carcasses and also from laboratory model mixtures containing $25 \%, 50 \%$, and $75 \%(\mathrm{w} / \mathrm{w})$ horse meat. A calibration dataset including 14 horse and 25 beef samples was used to create a PCA model based on the preprocessed Raman spectra data. Samples from the validation dataset included four horse and six beef meat samples, which were all correctly identified. The performance of the developed model was then tested using the model meat mixtures adulterated with horse meat, which appeared on the PCA plot separated from the single meat. Even though the authors concluded that the developed Raman method was capable of successfully identifying beef containing $25 \%$ of horse meat, they stated that more tests should be performed on a higher number of samples, corroborating the idea that the results from this proof-of-concept study should not be overinterpreted. Raman spectroscopy was also suggested for the classification of frankfurters made of chicken, turkey, and mixed meats (Campos et al., 2014) by the use of training and test sets comprising 38 and 19 samples, respectively. A drawback 
of this study was the fact that all the samples used to construct the model were commercially acquired, so there was no assurance that they actually contained the meat stated on the labels. Additionally, the proportion of correctly classified samples for the test set was only equal to or higher than $90 \%$, with best results being obtained for the meat mixture frankfurters. A similar approach was performed by Restaino et al. (2011), who aimed at discriminating meat pâtés according to the animal species by means of NIR spectroscopy and chemometrics. Both beef $(n=5)$ and pork pâtés $(n=7)$ were correctly classified using PCA followed by stepwise linear discriminant analysis, while pork and beef mixture pâtés $(n=18)$ only achieved a $72 \%$ correct classification. Again, the number of samples used in this study should be considered too low to make any authoritative conclusions. The use of NIR spectroscopy, UV-visible (UV-Vis), and MIR was investigated by Alamprese et al. (2013) for the detection of minced beef adulteration by turkey meat. By comparing the developed PLS regression models in terms of prediction errors, best results tested were obtained with NIR spectra. Nevertheless, considering the root mean square error of prediction values obtained (5.79-9.22), the method was more suited to be used for preliminary sample screening. Mamani-Linares et al. (2012) proposed to use visible and NIR reflectance spectroscopy to discriminate meat and meat juices from beef, llama, and horse. From a total of 79 samples (31 from beef, 21 from llama, and 27 from horse, acquired in different shops to increase sample diversity) most were correctly classified, although a few (six) were classified as uncertain. The authors suggested that broadening the calibration set by including more samples of different years, geographic origin, animal breeds, production systems, and muscles could contribute to develop more robust models.

Recently, the performance of three different methods based on NIR spectroscopy was evaluated for detecting adulteration of pure veal sausages with pork meat or fat, namely, a high-performance Fourier-transform-NIR (FT-NIR) laboratory desktop device, an FT-NIR equipped with a fiber-optic probe suitable for industrial application and a handheld FT-NIR spectrometer for on-site use (Schmutzler et al., 2015). After pretreatment of spectral data, PCA scores were used as input data for support vector machines classification and validation. Both the laboratory setup and the industrial fiber-optic setup were able to detect up to the lowest level of adulteration tested $[10 \%(\mathrm{w} / \mathrm{w})$ pork meat or fat], even when measurements were made through the polymer packaging instead of using a quartz cuvette. Similar results were obtained with the handheld equipment for sausages adulterated with pork meat, though without enabling the detection of pork fat at levels lower than $20 \%$ (w/w); measurements through the polymer packaging were possible down to this level.

The use of NIR spectroscopy coupled to image analysis has also been discussed as a fast, low-cost, and proper alternative since hyperspectral imaging integrates both spectroscopic and imaging techniques in one system, providing both spectral and spatial information simultaneously. Kamruzzaman et al. (2013) used NIR hyperspectral imaging for the detection of adulteration in minced lamb meats, as well as to detect the level of horse meat adulteration in minced beef (Kamruzzaman et al., 2015). In each case, the authors selected four important wavelengths that were used to build up a model and an image processing algorithm was developed to apply 
the model to each pixel in the image. This approach integrates spectroscopy and image analysis, providing both spectral and spatial information simultaneously, thus allowing to detect a particular type of meat and its distribution in the analyzed sample. In both studies, results demonstrated that hyperspectral imaging coupled with multivariate analysis could be successfully applied as a rapid screening technique for meat adulteration detection. Another technique tested for meat authentication is ${ }^{1} \mathrm{H}$ NMR spectroscopy. Jakes et al. (2015) proposed a methodology to distinguish beef from horse meat based on exploiting triglyceride signatures obtained by $60 \mathrm{MHz}{ }^{1} \mathrm{H}$ NMR spectroscopy. The protocol included a simple chloroform extraction and was tested in two different laboratories for horse and beef meat, including freeze-thawed samples. The model developed was then applied to 107 extracts prepared from independent samples resulting in all but one being correctly authenticated. The technique proved to be fast, low cost, and simple to use, being a potential alternative as a high-throughput approach for screening raw meat.

\subsection{Final Remarks}

Species identification in meats and meat products has been the subject of an increasing number of reports because of its importance in food authentication and to major advances in analytical methods. Both proteins and DNA have been the main target molecules for method development, but the latter have been preferred. Without targeting particular molecules, the spectroscopic methods have also advanced very recently for meat species identification based on Raman, FTIR, NIR, and $\mathrm{H}^{1}$ NMR. If, on the one hand, they can offer advantages, such as simple use, speed, low cost, and minimal or no sample extraction/preparation, on the other hand they still lack applicability, mainly to meat mixtures, and mostly rely on chemometrics after constructing suitable spectra databases. Protein-based methods have demonstrated their effectiveness in meat species identification by means of electrophoretic, immunochemical, and chromatographic techniques. Recent advances in MS have prompted the development of proteomic approaches for meat species differentiation based on the high discriminant power of peptide biomarkers, which have enhanced specificity when compared to other protein methods.

DNA-based methods play a crucial role in meat species identification because the advantages of specificity, sensitivity, simplicity, and low cost can be combined with their application to complex and processed food matrices. Species-specific PCR methods targeting mainly mtDNA markers are the most commonly used approaches for meat species detection in a wide range of meat products, covering all the domestic and game meat species used as food. For increased specificity and quantitative purposes, real-time PCR with TaqMan probes have also been extensively applied in meat species identification, being more recently the most reported technique. For high-throughput species identification, DNA chips are emerging as potential tools for multiple-species detection, but still need to improve sensitivity and applicability. Recent technological improvements have revolutionized genomics with the advent of NGS, which has rapidly become a key technology in basic science and only recently 
applied in meat species identification. The great potential for meat species identification arises from the possibility of identifying more than one species at the same time, including also unexpected or untargeted species, without any previous information about their presence, based on the high-throughput reads and bioinformatics. These advantages are worth exploiting in the near future for forensic food analysis and identifying fraudulent practices in meat and in meat-derived foods.

\section{References}

Abdulmawjood, A., Bülte, M., 2002. Identification of ostrich meat by restriction fragment length polymorphism (RFLP) analysis of cytochrome b gene. Journal of Food Science 67, $1688-1691$.

Aida, A.A., Che Man, Y.B., Wong, C.M.V.L., Raha, A.R., Son, R., 2005. Analysis of raw meats and fats of pigs using polymerase chain reaction for Halal authentication. Meat Science 69, 47-52.

Alamprese, C., Casale, M., Sinelli, N., Lanteri, S., Casiraghi, E., 2013. Detection of minced beef adulteration with turkey meat by UV-vis, NIR and MIR spectroscopy. LWT-Food Science and Technology 53, 225-232.

Ali, M.E., Al Amin, M., Hamid, S.B.A., Hossain, M.A.M., Mustafa, S., 2015a. Lab-on-a-chipbased PCR-RFLP assay for the confirmed detection of short-length feline DNA in food. Food Additives \& Contaminants: Part A 32, 1373-1383.

Ali, M.E., Hashim, U., Dhahi, T.S., Mustafa, S., Man, Y.B.C., Latif, M.A., 2012c. Analysis of pork adulteration in commercial burgers targeting porcine-specific mitochondrial cytochrome B gene by TaqMan probe real-time polymerase chain reaction. Food Analytical Methods 5, 784-794.

Ali, M.E., Hashim, U., Mustafa, S., Che Man, Y., 2012a. Swine-specific PCR-RFLP assay targeting mitochondrial cytochrome $b$ gene for semiquantitative detection of pork in commercial meat products. Food Analytical Methods 5, 613-623.

Ali, M.E., Hashim, U., Mustafa, S., Man, Y.B.C., Adam, T., Humayun, Q., 2014c. Nanobiosensor for the detection and quantification of pork adulteration in meatball formulation. Journal of Experimental Nanoscience 9, 152-160.

Ali, M.E., Hashim, U., Mustafa, S., Man, Y.B.C., Latif, M.A., Islam, K.N., Bakar, M., Rahman, M.M., 2012b. TaqMan real-time polymerase chain reaction for the determination of pork adulteration in meat nuggets. Journal of Food and Nutrition Research 51, 1-12.

Ali, M.E., Hashim, U., Mustafa, S., Man, Y.B.C., Yusop, M.H.M., Kashif, M., Dhahi, T.S., Bari, M.F., Hakim, M.A., Latif, M.A., 2011. Nanobiosensor for detection and quantification of DNA sequences in degraded mixed meats. Journal of Nanomaterials 11. Article ID 781098.

Ali, M.E., Mustafa, S., Hashim, U., Man, Y.B.C., Foo, K.L., 2012d. Nanobioprobe for the determination of pork adulteration in burger formulations. Journal of Nanomaterials 7. Article ID 832387.

Ali, M.E., Rahman, M.M., Hamid, S., Mustafa, S., Bhassu, S., Hashim, U., 2014a. Caninespecific PCR assay targeting cytochrome $b$ gene for the detection of dog meat adulteration in commercial frankfurters. Food Analytical Methods 7, 234-241.

Ali, M.E., Razzak, M.A., Hamid, S., 2014b. Multiplex PCR in species authentication: probability and prospects-a review. Food Analytical Methods 7, 1933-1949. 
Ali, M.E., Razzak, M.A., Hamid, S.B.A., Rahman, M.M., Amin, M.A., Rashid, N.R.A., Asing, 2015b. Multiplex PCR assay for the detection of five meat species forbidden in Islamic foods. Food Chemistry 177, 214-224.

Amaral, J.S., Santos, C.G., Melo, V.S., Costa, J., Oliveira, M.B.P.P., Mafra, I., 2015. Identification of duck, partridge, pheasant, quail, chicken and turkey meats by species-specific PCR assays to assess the authenticity of traditional game meat Alheira sausages. Food Control 47, 190-195.

Amaral, J.S., Santos, C.G., Melo, V.S., Oliveira, M.B.P.P., Mafra, I., 2014. Authentication of a traditional game meat sausage (Alheira) by species-specific PCR assays to detect hare, rabbit, red deer, pork and cow meats. Food Research International 60, 140-145.

Arslan, A.L.I., Ilhak, I., Calicioglu, M., Karahan, M., 2005. Identification of meats using random amplified polymorphic DNA (RAPD) technique. Journal of Muscle Foods 16, 37-45.

Asensio, L., Gonzalez, I., Garcia, T., Martin, R., 2008. Determination of food authenticity by enzyme-linked immunosorbent assay (ELISA). Food Control 19, 1-8.

Ballin, N.Z., 2010. Authentication of meat and meat products. Meat Science 86, 577-587.

Ballin, N.Z., Vogensen, F.K., Karlsson, A.H., 2009. Species determination - can we detect and quantify meat adulteration? Meat Science 83, 165-174.

von Bargen, C., Brockmeyer, J., Humpf, H.-U., 2014. Meat authentication: a new HPLC-MS/ MS based method for the fast and sensitive detection of horse and pork in highly processed food. Journal of Agricultural and Food Chemistry 62, 9428-9435.

von Bargen, C., Dojahn, J., Waidelich, D., Humpf, H.-U., Brockmeyer, J., 2013. New sensitive high-performance liquid chromatography tandem mass spectrometry method for the detection of horse and pork in Halal beef. Journal of Agricultural and Food Chemistry 61, 11986-11994.

Bertolini, F., Ghionda, M.C., D’Alessandro, E., Geraci, C., Chiofalo, V., Fontanesi, L., 2015. A next generation semiconductor based sequencing approach for the identification of meat species in DNA mixtures. PLoS One 10, e0121701.

Boyaci, I.H., Temiz, H.T., Uysal, R.S., Velioglu, H.M., Yadegari, R.J., Rishkan, M.M., 2014. A novel method for discrimination of beef and horsemeat using Raman spectroscopy. Food Chemistry $148,37-41$.

Buckley, M., Melton, N.D., Montgomery, J., 2013. Proteomics analysis of ancient food vessel stitching reveals $>4000$-year-old milk protein. Rapid Communications in Mass Spectrometry $27,531-538$.

Buermans, H.P.J., den Dunnen, J.T., 2014. Next generation sequencing technology: advances and applications. Biochimica et Biophysica Acta (BBA) - Molecular Basis of Disease 1842, 1932-1941.

Calvo, J.H., Zaragoza, P., Osta, R., 2001. Random amplified polymorphic DNA fingerprints for identification of species in poultry pâté. Poultry Science 80, 522-524.

Campos, N.D.S., Oliveira, K.S., Almeida, M.R., Stephani, R., de Oliveira, L.F.C., 2014. Classification of frankfurters by FT-Raman spectroscopy and chemometric methods. Molecules 19, 18980-18992.

Chen, A., Wei, C., Chen, G., Zhao, Y., Yang, S., 2015. Duplex PCR approach for the detection and quantification of donkey, horse and mule in raw and heat-processed meat products. International Journal of Food Science \& Technology 50, 834-839.

Chen, F.C., Hsieh, Y.H.P., 2000. Detection of pork in heat-processed meat products by monoclonal antibody-based ELISA. Journal of AOAC International 83, 79-85.

Chen, F.C., Hsieh, Y.H.P., Bridgman, R.C., 1998. Monoclonal antibodies to porcine thermalstable muscle protein for detection of pork in raw and cooked meats. Journal of Food Science 63, 201-205. 
Chen, Y., Wu, Y., Wang, J., Xu, B., Zhong, Z., Xia, J., 2009. Identification of cervidae DNA in feedstuff using a real-time polymerase chain reaction method with the new fluorescence intercalating dye EvaGreen. Journal of AOAC International 92, 175-180.

Cheng, X., He, W., Huang, F., Huang, M., Zhou, G., 2014. Multiplex real-time PCR for the identification and quantification of DNA from duck, pig and chicken in Chinese blood curds. Food Research International 60, 30-37.

Chisholm, J., Conyers, C., Booth, C., Lawley, W., Hird, H., 2005. The detection of horse and donkey using real-time PCR. Meat Science 70, 727-732.

Colombo, F., Cardia, A., Renon, P., Cantoni, C., 2004. A note on the identification of Rupicapra rupicapra species by polymerase chain reaction product sequencing. Meat Science 66, 753-755.

Colombo, F., Marchisio, E., Pizzini, A., Cantoni, C., 2002. Identification of the goose species (Anser anser) in Italian "Mortara" salami by DNA sequencing and a polymerase chain reaction with an original primer pair. Meat Science 61, 291-294.

Conyers, C.M., Allnutt, T.R., Hird, H.J., Kaye, J., Chisholm, J., 2012. Development of a microsatellite-based method for the differentiation of European wild boar (Sus scrofa scrofa) from domestic pig breeds (Sus scrofa domestica) in food. Journal of Agricultural and Food Chemistry 60, 3341-3347.

Costa, H., Mafra, I., Oliveira, M.B.P.P., Amaral, J.S., 2016a. Game: types and composition. In: Caballero, B., Finglas, P., Toldrá, F. (Eds.), The Encyclopedia of Food and Health, vol. 3. Academic Press, Oxford, pp. 177-183.

Costa, J., Mafra, I., Carrapatoso, I., Oliveira, M.B.P.P., 2016b. Hazelnut allergens: molecular characterisation, detection and clinical relevance. Critical Reviews in Food Science and Nutrition. http://dx.doi.org/10.1080/10408398.2013.826173.

Cota-Rivas, M., Vallejo-Cordoba, B., 1997. Capillary electrophoresis for meat species differentiation. Journal of Capillary Electrophoresis 4, 195-199.

D'Amato, M.E., Alechine, E., Cloete, K.W., Davison, S., Corach, D., 2013. Where is the game? Wild meat products authentication in South Africa: a case study. Investigative Genetics 4, $1-13$.

Dalmasso, A., Fontanella, E., Piatti, P., Civera, T., Rosati, S., Bottero, M.T., 2004. A multiplex PCR assay for the identification of animal species in feedstuffs. Molecular and Cellular Probes 18, 81-87.

Dalton, D.L., Kotze, A., 2011. DNA barcoding as a tool for species identification in three forensic wildlife cases in South Africa. Forensic Science International 207, e51-e54.

van Dijk, E.L., Auger, H., Jaszczyszyn, Y., Thermes, C., 2014. Ten years of next-generation sequencing technology. Trends in Genetics 30, 418-426.

Djurdievic, N., Sheu, S.C., Hsieh, Y.H.P., 2005. Quantitative detection of poultry in cooked meat products. Journal of Food Science 70, C586-C593.

Dooley, J.J., Paine, K.E., Garrett, S.D., Brown, H.M., 2004. Detection of meat species using TaqMan real-time PCR assays. Meat Science 68, 431-438.

Doosti, A., Ghasemi Dehkordi, P., Rahimi, E., 2014. Molecular assay to fraud identification of meat products. Journal of Food Science and Technology 51, 148-152.

Druml, B., Cichna-Markl, M., 2014. High resolution melting (HRM) analysis of DNA - its role and potential in food analysis. Food Chemistry 158, 245-254.

Druml, B., Grandits, S., Mayer, W., Hochegger, R., Cichna-Markl, M., 2015a. Authenticity control of game meat products - a single method to detect and quantify adulteration of fallow deer (Dama dama), red deer (Cervus elaphus) and sika deer (Cervus nippon) by realtime PCR. Food Chemistry 170, 508-517. 
Druml, B., Hochegger, R., Cichna-Markl, M., 2015b. Duplex real-time PCR assay for the simultaneous determination of the roe deer (Capreolus capreolus) and deer (sum of fallow deer, red deer and sika deer) content in game meat products. Food Control 57, 370-376.

Druml, B., Mayer, W., Cichna-Markl, M., Hochegger, R., 2015c. Development and validation of a TaqMan real-time PCR assay for the identification and quantification of roe deer (Capreolus capreolus) in food to detect food adulteration. Food Chemistry 178, 319-326.

Drummond, M.G., Brasil, B., Dalsecco, L.S., Brasil, R., Teixeira, L.V., Oliveira, D.A.A., 2013. A versatile real-time PCR method to quantify bovine contamination in buffalo products. Food Control 29, 131-137.

Espiñeira, M., Vieites, J.M., 2015. Detection of dog and cat traces in food, pet food and farm animal feed by real-time PCR. European Food Research and Technology 241, 233-238.

Etienne, M., Jerome, M., Fleurence, J., Rehbein, H., Kundiger, R., Mendes, R., Costa, H., PerezMartin, R., Pineiro-Gonzalez, C., Craig, A., Mackie, I., Yman, I.M., Ferm, M., Martinez, I., Jessen, F., Smelt, A., Luten, J., 2000. Identification of fish species after cooking by SDSPAGE and urea IEF: a collaborative study. Journal of Agricultural and Food Chemistry 48, 2653-2658.

European Commission, 2001. Directive 2001/101/EC of 26 November 2001 amending Directive 2000/13/EC of the European Parliament and of the Council on the approximation of 20 March 2000 on the approximation of the laws of the Member States relating to the labelling, presentation and advertising of foodstuffs. Official Journal of the European Communities L310, 19-21.

European Commission, 2002. Regulation (EC) No 178/2002 of the European Parliament and of the Council of 28 January 2002 laying down the general principles and requirements of food law, establishing the European Food Safety Authority and laying down procedures in matters of food safety. Official Journal of the European Communities L 31, 1-24.

Fajardo, V., González, I., Dooley, J., Garret, S., Brown, H.M., García, T., Martín, R., 2009a. Application of polymerase chain reaction-restriction fragment length polymorphism analysis and lab-on-a-chip capillary electrophoresis for the specific identification of game and domestic meats. Journal of the Science of Food and Agriculture 89, 843-847.

Fajardo, V., González, I., López-Calleja, I., Martín, I., Hernández, P.E., Garcia, T., Martín, R., 2006. PCR-RFLP Authentication of meats from red deer (Cervus elaphus), fallow deer (Dama dama), roe deer (Capreolus capreolus), cattle (Bos taurus), sheep (Ovis aries), and goat (Capra hircus). Journal of Agricultural and Food Chemistry 54, 1144-1150.

Fajardo, V., González, I., López-Calleja, I., Martín, I., Rojas, M., Garcia, T., Hernandez, P.E., Martin, R., 2007c. PCR identification of meats from chamois (Rupicapra rupicapra), pyrenean ibex (Capra pyrenaica), and mouflon (Ovis ammon) targeting specific sequences from the mitochondrial D-loop region. Meat Science 76, 644-652.

Fajardo, V., González, I., López-Calleja, I., Martín, I., Rojas, M., Pavón, M.Á., Hernández, P.E., García, T., Martín, R., 2007a. Analysis of mitochondrial DNA for authentication of meats from chamois (Rupicapra rupicapra), pyrenean ibex (Capra pyrenaica), and mouflon (Ovis ammon) by polymerase chain reaction-restriction fragment length polymorphism. Journal of AOAC International 90, 179-186.

Fajardo, V., González, I., López-Calleja, I., Martín, I., Rojas, M., Hernández, P.E., García, T., Martín, R., 2007b. Identification of meats from red deer (Cervus elaphus), fallow deer (Dama dama), and roe deer (Capreolus capreolus) using polymerase chain reaction targeting specific sequences from the mitochondrial 12S rRNA gene. Meat Science 76, 234-240. 
Fajardo, V., Gonzalez, I., Martin, I., Rojas, M., Hernandez, P.E., Garcia, T., Martin, R., 2008. Differentiation of European wild boar (Sus scrofa scrofa) and domestic swine (Sus scrofa domestica) meats by PCR analysis targeting the mitochondrial D-loop and the nuclear melanocortin receptor 1 (MC1R) genes. Meat Science 78, 314-322.

Fajardo, V., Gonzalez, I., Martin, I., Rojas, M., Hernandez, P.E., Garcia, T., Martin, R., 2009b. A LightCycler TaqMan PCR assay for quantitative detection of chamois (Rupicapra rupicapra) and pyrenean ibex (Capra pyrenaica) in experimental meat mixtures. International Journal of Food Science and Technology 44, 1997-2004.

Fajardo, V., González, I., Rojas, M., García, T., Martín, R., 2010. A review of current PCRbased methodologies for the authentication of meats from game animal species. Trends in Food Science \& Technology 21, 408-421.

Fang, X., Zhang, C., 2016. Detection of adulterated murine components in meat products by TaqMan real-time PCR. Food Chemistry 192, 485-490.

Farrokhi, R., Joozani, R.J., 2011. Identification of pork genome in commercial meat extracts for Halal authentication by SYBR green I real-time PCR. International Journal of Food Science and Technology 46, 951-955.

Galimberti, A., De Mattia, F., Losa, A., Bruni, I., Federici, S., Casiraghi, M., Martellos, S., Labra, M., 2013. DNA barcoding as a new tool for food traceability. Food Research International 50, 55-63.

Ghovvati, S., Nassiri, M.R., Mirhoseini, S.Z., Moussavi, A.H., Javadmanesh, A., 2009. Fraud identification in industrial meat products by multiplex PCR assay. Food Control 20, 696-699.

Giaretta, N., Di Giuseppe, A.M.A., Lippert, M., Parente, A., Di Maro, A., 2013. Myoglobin as marker in meat adulteration: a UPLC method for determining the presence of pork meat in raw beef burger. Food Chemistry 141, 1814-1820.

Giovannacci, I., Guizard, C., Carlier, M., Duval, V., Martin, J.L., Demeulemester, C., 2004. Species identification of meat products by ELISA. International Journal of Food Science and Technology 39, 863-867.

Girish, P.S., Anjaneyulu, A.S.R., Viswas, K.N., Anand, M., Rajkumar, N., Shivakumar, B.M., Bhaskar, S., 2004. Sequence analysis of mitochondrial 12S rRNA gene can identify meat species. Meat Science 66, 551-556.

Girish, P.S., Anjaneyulu, A.S.R., Viswas, K.N., Shivakumar, B.M., Anand, M., Patel, M., Sharma, B., 2005. Meat species identification by polymerase chain reaction-restriction fragment length polymorphism (PCR-RFLP) of mitochondrial 12S rRNA gene. Meat Science 70, 107-112.

Girish, P., Anjaneyulu, A., Viswas, K., Santhosh, F., Bhilegaonkar, K., Agarwal, R., Kondaiah, N., Nagappa, K., 2007. Polymerase chain reaction-restriction fragment length polymorphism of mitochondrial 12S rRNA gene: a simple method for identification of poultry meat species. Veterinary Research Communications 31, 447-455.

Ha, J.C., Jung, W.T., Nam, Y.S., Moon, T.W., 2006. PCR identification of ruminant tissue in raw and heat-treated meat meals. Journal of Food Protection 69, 2241-2247.

Haider, N., Nabulsi, I., Al-Safadi, B., 2012. Identification of meat species by PCR-RFLP of the mitochondrial COI gene. Meat Science 90, 490-493.

Haunshi, S., Basumatary, R., Girish, P.S., Doley, S., Bardoloi, R.K., Kumar, A., 2009. Identification of chicken, duck, pigeon and pig meat by species-specific markers of mitochondrial origin. Meat Science 83, 454-459.

Hebert, P.D.N., Cywinska, A., Ball, S.L., de Waard, J.R., 2003. Biological identifications through DNA barcodes. Proceedings of the Royal Society of London. Series B: Biological Sciences 270, 313-321. 
Hellberg, R.S.R., Morrissey, M.T., 2011. Advances in DNA-based techniques for the detection of seafood species substitution on the commercial market. Journal of the Association for Laboratory Automation 16, 308-321.

Hernández-Chávez, J.F., González-Córdova, A.F., Rodríguez-Ramírez, R., Vallejo-Cordoba, B., 2011. Development of a polymerase chain reaction and capillary gel electrophoresis method for the detection of chicken or turkey meat in heat-treated pork meat mixtures. Analytica Chimica Acta 708, 149-154.

Hird, H., Chisholm, J., Brown, J., 2005. The detection of commercial duck species in food using a single probe-multiple species-specific primer real-time PCR assay. European Food Research and Technology 221, 559-563.

Hofmann, K., 1985. Principal problems in the identification of meat species of alaughter animals using electrophoretic methods. In: Patterson, R.L.S. (Ed.), Biochemical identification of meat species. Elsevier, London, pp. 9-31.

Horreo, J.L., Ardura, A., Pola, I.G., Martinez, J.L., Garcia-Vazquez, E., 2013. Universal primers for species authentication of animal foodstuff in a single polymerase chain reaction. Journal of the Science of Food and Agriculture 93, 354-361.

Hou, B., Meng, X., Zhang, L., Guo, J., Li, S., Jin, H., 2015. Development of a sensitive and specific multiplex PCR method for the simultaneous detection of chicken, duck and goose DNA in meat products. Meat Science 101, 90-94.

Hung, C.-J., Ho, H.-P., Chang, C.-C., Lee, M.-R., Franje, C.A., Kuo, S.-I., Lee, R.-J., Chou, C.-C., 2011. Electrochemical profiling using copper nanoparticle-plated electrode for identification of ostrich meat and evaluation of meat grades. Food Chemistry 126, 1417-1423.

Ilhak, O.I., Arslan, A., 2007. Identification of meat species by polymerase chain reaction (PCR) technique. Turkish Journal of Veterinary and Animal Sciences 31, 159-163.

Iwobi, A.N., Huber, I., Hauner, G., Miller, A., Busch, U., 2011. Biochip technology for the detection of animal species in meat products. Food Analytical Methods 4, 389-398.

Iwobi, A., Sebah, D., Kraemer, I., Losher, C., Fischer, G., Busch, U., Huber, I., 2015. A multiplex real-time PCR method for the quantification of beef and pork fractions in minced meat. Food Chemistry 169, 305-313.

Jakes, W., Gerdova, A., Defernez, M., Watson, A.D., McCallum, C., Limer, E., Colquhoun, I.J., Williamson, D.C., Kemsley, E.K., 2015. Authentication of beef versus horse meat using 60 $\mathrm{MHz}{ }^{1} \mathrm{H}$ NMR spectroscopy. Food Chemistry 175, 1-9.

Jonker, K.M., Tilburg, J., Hagele, G.H., De Boer, E., 2008. Species identification in meat products using real-time PCR. Food Additives and Contaminants 25, 527-533.

Kaiser, K.P., Matheis, G., Kmita-Dürrmann, C., Belitz, H.D., 1980. Qualitative and quantitative analysis of raw binary meat mixtures by means of isoelectric focusing in polyacrylamide gel. Zeitschrift für Lebensmittel-Untersuchung und Forschung 171, 415-419.

Kamruzzaman, M., Makino, Y., Oshita, S., Liu, S., 2015. Assessment of visible near-infrared hyperspectral imaging as a tool for detection of horsemeat adulteration in minced beef. Food and Bioprocess Technology 8, 1054-1062.

Kamruzzaman, M., Sun, D.W., El Masry, G., Allen, P., 2013. Fast detection and visualization of minced lamb meat adulteration using NIR hyperspectral imaging and multivariate image analysis. Talanta 103, 130-136.

Kane, D.E., Hellberg, R.S., 2016. Identification of species in ground meat products sold on the U.S. commercial market using DNA-based methods. Food Control 59, 158-163.

Karabasanavar, N.S., Singh, S.P., Kumar, D., Shebannavar, S.N., 2014. Detection of pork adulteration by highly-specific PCR assay of mitochondrial D-loop. Food Chemistry 145, $530-534$. 
Karabasanavar, N., Singh, S.P., Kumar, D., Shebannavar, S., 2013. Development and application of highly specific PCR for detection of chicken (Gallus gallus) meat adulteration. European Food Research and Technology 236, 129-134.

Kesmen, Z., Gulluce, A., Sahin, F., Yetim, H., 2009. Identification of meat species by TaqManbased real-time PCR assay. Meat Science 82, 444-449.

Kesmen, Z., Sahin, F., Yetim, H., 2007. PCR assay for the identification of animal species in cooked sausages. Meat Science 77, 649-653.

Kim, H., Shelef, L.A., 1986. Characterization and identification of raw beef, pork, chicken and turkey meats by electrophoretic patterns of their sarcoplasmic proteins. Journal of Food Science 51, 731-735.

Köppel, R., Daniels, M., Felderer, N., Brünen-Nieweler, C., 2013. Multiplex real-time PCR for the detection and quantification of DNA from duck, goose, chicken, turkey and pork. European Food Research and Technology 236, 1093-1098.

Kotoura, S.Y., Murakami-Yamaguchi, K., Kizu, Nakamura, M., Fuchu, H., Miake, K., Sugiyama, M., Narita, H., 2012. Establishment of a sandwich ELISA for the determination of beef content in processed foods by using monoclonal antibodies to myoglobin. Food and Agricultural Immunology 23, 289-301.

Kumar, D., Singh, S.P., Karabasanavar, N., Singh, R., Umapathi, V., 2014. Authentication of beef, carabeef, chevon, mutton and pork by a PCR-RFLP assay of mitochondrial cytb gene. Journal of Food Science and Technology 51, 3458-3463.

Laube, I., Zagon, J., Spiegelberg, A., Butschke, A., Kroh, L.W., Broll, H., 2007. Development and design of a 'ready-to-use' reaction plate for a PCR-based simultaneous detection of animal species used in foods. International Journal of Food Science \& Technology 42, 9-17.

Liu, L.H., Chen, F.C., Dorsey, J.L., Hsieh, Y.H.P., 2006. Sensitive monoclonal antibody-based sandwich ELISA for the detection of porcine skeletal muscle in meat and feed products. Journal of Food Science 71, M1-M6.

López, B.L., Binaghi, J.M., Greco, B.C., Mambrín, C.M., Valencia, E.M., 2011. Identificación de especies cárnicas en productos cárnicos cocidos: utilización de SDS-PAGE como método de screening. Revista Chilena de Nutrición 38, 187-196.

López-Andreo, M., Aldeguer, M., Guillén, I., Gabaldón, J.A., Puyet, A., 2012. Detection and quantification of meat species by qPCR in heat-processed food containing highly fragmented DNA. Food Chemistry 134, 518-523.

Luo, A., Zhang, A., Ho, S.Y., Xu, W., Zhang, Y., Shi, W., Cameron, S.L., Zhu, C., 2011. Potential efficacy of mitochondrial genes for animal DNA barcoding: a case study using eutherian mammals. BMC Genomics 12, 1-13.

Maede, D., 2006. A strategy for molecular species detection in meat and meat products by PCRRFLP and DNA sequencing using mitochondrial and chromosomal genetic sequences. European Food Research and Technology 224, 209-217.

Mafra, I., Ferreira, I.M.P.L.V.O., Oliveira, M.B.P.P., 2008. Food authentication by PCR-based methods. European Food Research and Technology 227, 649-665.

Mamani-Linares, L.W., Gallo, C., Alomar, D., 2012. Identification of cattle, llama and horse meat by near infrared reflectance or transflectance spectroscopy. Meat Science 90, $378-385$.

Mane, B.G., Mendiratta, S.K., Tiwari, A.K., 2009. Polymerase chain reaction assay for identification of chicken in meat and meat products. Food Chemistry 116, 806-810.

Mane, B.G., Mendiratta, S.K., Tiwari, A.K., 2012a. Beef specific polymerase chain reaction assay for authentication of meat and meat products. Food Control 28, 246-249. 
Mane, B.G., Mendiratta, S.K., Tiwari, A.K., Bhilegaokar, K.N., 2012b. Detection of adulteration of meat and meat products with buffalo meat employing polymerase chain reaction assay. Food Analytical Methods 5, 296-300.

Martín, I., García, T., Fajardo, V., López-Calleja, I., Hernández, P.E., González, I., Martín, R., 2007a. Species-specific PCR for the identification of ruminant species in feedstuffs. Meat Science 75, 120-127.

Martín, I., García, T., Fajardo, V., López-Calleja, I., Rojas, M., Hernández, P.E., González, I., Martín, R., 2007b. Mitochondrial markers for the detection of four duck species and the specific identification of Muscovy duck in meat mixtures using the polymerase chain reaction. Meat Science 76, 721-729.

Martín, I., García, T., Fajardo, V., Rojas, M., Pegels, N., Hernández, P.E., González, I., Martín, R., 2009. Polymerase chain reaction detection of rabbit DNA in food and animal feed. World Rabbit Science 17, 27-34.

Matsunaga, T., Chikuni, K., Tanabe, R., Muroya, S., Nakai, H., Shibata, K., Yamada, J., Shinmura, Y., 1998. Determination of mitochondrial cytochrome b gene sequence for red deer (Cervus elaphus) and the differentiation of closely related deer meats. Meat Science 49, 379-385.

Matsunaga, T., Chikuni, K., Tanabe, R., Muroya, S., Shibata, K., Yamada, J., Shinmura, Y., 1999. A quick and simple method for the identification of meat species and meat products by PCR assay. Meat Science 51, 143-148.

Meyer, R., Candrian, U., Lüthy, J., 1994. Detection of pork in heated meat products by the polymerase chain reaction. Journal of AOAC International 77, 617-622.

Meyer, R., Höfelein, C., Lüthy, J., Candrian, U., 1995. Polymerase chain reaction-restriction fragment length polymorphism analysis: a simple method for species identification in food. Journal of AOAC International 78, 1542-1551.

Montiel-Sosa, J.F., Ruiz-Pesini, E., Montoya, J., Roncalés, P., López-Pérez, M.J., PérezMartos, A., 2000. Direct and highly species-specific detection of pork meat and fat in meat products by PCR amplification of mitochondrial DNA. Journal of Agricultural and Food Chemistry 48, 2829-2832.

Montowska, M., Pospiech, E., 2007. Species identification of meat by electrophoretic methods. Acta Scientiarum Polonorum Technologia Alimentaria 6, 5-16.

Montowska, M., Pospiech, E., 2011a. Authenticity determination of meat and meat products on the protein and DNA basis. Food Reviews International 27, 84-100.

Montowska, M., Pospiech, E., 2011b. Differences in two-dimensional gel electrophoresis patterns of skeletal muscle myosin light chain isoforms between Bos taurus, Sus scrofa and selected poultry species. Journal of the Science of Food and Agriculture 91, 2449-2456.

Montowska, M., Pospiech, E., 2012a. Is authentication of regional and traditional food made of meat possible? Critical Reviews in Food Science and Nutrition 52, 475-487.

Montowska, M., Pospiech, E., 2012b. Myosin light chain isoforms retain their species-specific electrophoretic mobility after processing, which enables differentiation between six species: 2DE analysis of minced meat and meat products made from beef, pork and poultry. Proteomics 12, 2879-2889.

Montowska, M., Alexander, M.R., Tucker, G.A., Barrett, D.A., 2014b. Rapid detection of peptide markers for authentication purposes in raw and cooked meat using ambient liquid extraction surface analysis mass spectrometry. Analytical Chemistry 86, 10257-10265.

Montowska, M., Alexander, M.R., Tucker, G.A., Barrett, D.A., 2015. Authentication of processed meat products by peptidomic analysis using rapid ambient mass spectrometry. Food Chemistry 187, 297-304. 
Montowska, M., Rao, W., Alexander, M.R., Tucker, G.A., Barrett, D.A., 2014a. Tryptic digestion coupled with ambient desorption electrospray ionization and liquid extraction surface analysis mass spectrometry enabling identification of skeletal muscle proteins in mixtures and distinguishing between beef, pork, horse, chicken, and turkey meat. Analytical Chemistry 6 (86), 4479-4487.

Mousavi, S.M., Jahed Khaniki, G., Eskandari, S., Rabiei, M., Mirab Samiee, S., Mehdizadeh, M., 2015. Applicability of species-specific polymerase chain reaction for fraud identification in raw ground meat commercially sold in Iran. Journal of Food Composition and Analysis 40, 47-51.

Murugaiah, C., Noor, Z.M., Mastakim, M., Bilung, L.M., Selamat, J., Radu, S., 2009. Meat species identification and Halal authentication analysis using mitochondrial DNA. Meat Science 83, 57-61.

Natonek-Wiśniewska, M., Krzyścin, P., Piestrzyńska-Kajtoch, A., 2013. The species identification of bovine, porcine, ovine and chicken components in animal meals, feeds and their ingredients, based on COX I analysis and ribosomal DNA sequences. Food Control 34, 69-78.

Nau, F., Désert, C., Cochet, M.-F., Pasco, M., Jan, S., Baron, F., Lagarrigue, S., GuérinDubiard, C., 2009. Detection of turkey, duck, and guinea fowl egg in hen egg products by species-specific PCR. Food Analytical Methods 2, 231-238.

Navarro, E., Serrano-Heras, G., Castaño, M.J., Solera, J., 2015. Real-time PCR detection chemistry. Clinica Chimica Acta 439, 231-250.

Nejad, F.P., Tafvizi, F., Ebrahimi, M.T., Hosseni, S.E., 2014. Optimization of multiplex PCR for the identification of animal species using mitochondrial genes in sausages. European Food Research and Technology 239, 533-541.

Nixon, G.J., Wilkes, T.M., Burns, M.J., 2015. Development of a real-time PCR approach for the relative quantitation of horse DNA. Analytical Methods 7, 8590-8596.

Pascoal, A., Prado, M., Calo, P., Cepeda, A., Barros-Velázquez, J., 2005. Detection of bovine DNA in raw and heat-processed foodstuffs, commercial foods and specific risk materials by a novel specific polymerase chain reaction method. European Food Research and Technology 220, 444-450.

Pascoal, A., Prado, M., Castro, J., Cepeda, A., Barros-Velásquez, J., 2004. Survey of authenticity of meat species in food products subjected to different technological processes, by means of PCR-RFLP analysis. European Food Research and Technology 218, 306-312.

Pegels, N., Garcia, T., Martin, R., Gonzalez, I., 2015. Market analysis of food and feed products for detection of horse DNA by a TaqMan real-time PCR. Food Analytical Methods 8, 489-498.

Pegels, N., Lopez-Calleja, I., Garcia, T., Martin, R., Gonzalez, I., 2013. Detection of rabbit and hare processed material in compound feeds by TaqMan real-time PCR. Food Additives and Contaminants Part A-Chemistry Analysis Control Exposure \& Risk Assessment 30, 771-779.

Pereira, F., Carneiro, J., Amorim, A., 2008. Identification of species with DNA-based technology: current progress and challenges. Recent Patents on DNA \& Gene Sequences 2, 187-200.

Pfeiffer, I., Burger, J., Brenig, B., 2004. Diagnostic polymorphisms in the mitochondrial cytochrome $\mathrm{b}$ gene allow discrimination between cattle, sheep, goat, roe buck and deer by PCR-RFLP. BMC Genetics 5, 30.

Quinto, C.A., Tinoco, R., Hellberg, R.S., 2016. DNA barcoding reveals mislabeling of game meat species on the US commercial market. Food Control 59, 386-392.

Rahman, M.M., Abd Hamid, S.B., Basirun, W.J., Bhassu, S., Rashid, N.R.A., Mustafa, S., Desa, M.N.M., Ali, M.E., 2016. TaqMan probe real-time polymerase chain reaction assay 
for the quantification of canine DNA in chicken nugget. Food Additives and Contaminants Part A - Chemistry Analysis Control Exposure \& Risk Assessment 33, 10-18.

Rahman, M.M., Ali, M.E., Hamid, S., Bhassu, S., Mustafa, S., Al Amin, M., Razzak, M.A., 2015. Lab-on-a-Chip PCR-RFLP Assay for the detection of canine DNA in burger formulations. Food Analytical Methods 8, 1598-1606.

Rahmania, H., Sudjadi, Rohman, A., 2015. The employment of FTIR spectroscopy in combination with chemometrics for analysis of rat meat in meatball formulation. Meat Science $100,301-305$.

Rastogi, G., Dharne, M.S., Walujkar, S., Kumar, A., Patole, M.S., Shouche, Y.S., 2007. Species identification and authentication of tissues of animal origin using mitochondrial and nuclear markers. Meat Science 76, 666-674.

Restaino, E., Fassio, A., Cozzolino, D., 2011. Discrimination of meat patés according to the animal species by means of near infrared spectroscopy and chemometrics. CyTA - Journal of Food 9, 210-213.

Ripp, F., Krombholz, C.F., Liu, Y., Weber, M., Schäfer, A., Schmidt, B., Köppel, R., Hankeln, T., 2014. All-Food-Seq (AFS): a quantifiable screen for species in biological samples by deep DNA sequencing. BMC Genomics 15, 1-11.

Rodríguez, M.A., García, T., González, I., Asensio, L., Hernández, P.E., Martín, R., 2004. PCR identification of beef, sheep, goat, and pork in raw and heat-treated meat mixtures. Journal of Food Protection 67, 172-177.

Rodríguez, M.A., García, T., González, I., Asensio, L., Hernández, P.E., Martín, R., 2003a. Qualitative PCR for the detection of chicken and pork adulteration in goose and mule duck foie gras. Journal of the Science of Food and Agriculture 83, 1176-1181.

Rodríguez, M.A., García, T., González, I., Asensio, L., Mayoral, B., López-Calleja, I., Hernández, P.E., Martín, R., 2003b. Identification of goose, mule duck, chicken, turkey, and swine in foie gras species-specific polymerase chain reaction. Journal of Agricultural and Food Chemistry 51, 1524-1529.

Rodriguez, M.A., Garcia, T., Gonzalez, I., Hernandez, P.E., Martin, R., 2005. TaqMan real-time PCR for the detection and quantitation of pork in meat mixtures. Meat Science 70, $113-120$.

Rohman, A., Sismindari, Erwanto, Y., Man, Y.B.C., 2011. Analysis of pork adulteration in beef meatball using Fourier transform infrared (FTIR) spectroscopy. Meat Science 88, 91-95.

Rojas, M., González, I., Fajardo, V., Martín, I., Hernández, P.E., García, T., Martín, R., 2009a. Identification of raw and heat-processed meats from game bird species by polymerase chain reaction-restriction fragment length polymorphism of the mitochondrial D-loop region. Poultry Science 88, 669-679.

Rojas, M., González, I., Fajardo, V., Martín, I., Hernández, P.E., García, T., Martín, R., 2009b. Authentication of meats from quail (Coturnix coturnix), pheasant (Phasianus colchicus), partridge (Alectoris spp.), and guinea fowl (Numida meleagris) using polymerase chain reaction targeting specific sequences from the mitochondrial $12 \mathrm{~S}$ rRNA gene. Food Control 20, 896-902.

Rojas, M., González, I., Fajardo, V., Martín, I., Hernández, P.E., García, T., Martín, R., 2008. Polymerase chain reaction-restriction fragment length polymorphism authentication of raw meats from game birds. Journal of AOAC International 91, 1416-1422.

Rojas, M., González, I., Pavón, M.A., Pegels, N., Hernández, P.E., García, T., Martín, R., 2010. Polymerase chain reaction assay for verifying the labeling of meat and commercial meat products from game birds targeting specific sequences from the mitochondrial D-loop region. Poultry Science 89, 1021-1032. 
Rojas, M., González, I., Pavón, M.Á., Pegels, N., Hernández, P.E., García, T., Martín, R., 2011. Development of a real-time PCR assay to control the illegal trade of meat from protected capercaillie species (Tetrao urogallus). Forensic Science International 210, 133-138.

Safdar, M., Abasiyanık, M.F., 2013. Development of fast multiplex real-time PCR assays based on EvaGreen fluorescence dye for identification of beef and soybean origins in processed sausages. Food Research International 54, 1652-1656.

Safdar, M., Junejo, Y., 2015. A multiplex-conventional PCR assay for bovine, ovine, caprine and fish species identification in feedstuffs: highly sensitive and specific. Food Control 50, 190-194.

Safdar, M., Junejo, Y., 2016. The development of a hexaplex-conventional PCR for identification of six animal and plant species in foodstuffs. Food Chemistry 192, 745-749.

Safdar, M., Junejo, Y., Arman, K., Abasıyanık, M.F., 2014. A highly sensitive and specific tetraplex PCR assay for soybean, poultry, horse and pork species identification in sausages: development and validation. Meat Science 98, 296-300.

Santos, C.G., Melo, V.S., Amaral, J.S., Estevinho, L., Oliveira, M.B.P.P., Mafra, I., 2012. Identification of hare meat by a species-specific marker of mitochondrial origin. Meat Science 90, 836-841.

Schmutzler, M., Beganovic, A., Boehler, G., Huck, C.W., 2015. Methods for detection of pork adulteration in veal product based on FT-NIR spectroscopy for laboratory, industrial and on-site analysis. Food Control 57, 258-267.

Sentandreu, M.A., Sentandreu, E., 2011. Peptide biomarkers as a way to determine meat authenticity. Meat Science 89, 280-285.

Sentandreu, M.A., Sentandreu, E., 2014. Authenticity of meat products: tools against fraud. Food Research International 60, 19-29.

Sentandreu, M.A., Fraser, P.D., Halket, J., Patel, R., Bramley, P.M., 2010. A proteomic-based approach for detection of chicken in meat mixes. Journal of Proteome Research 9, 3374-3383.

Skarpeid, H.J., Kvaal, K., Hildrum, K.I., 1998. Identification of animal species in ground meat mixtures by multivariate analysis of isoelectric focusing protein profiles. Electrophoresis 19, 3103-3109.

Slattery, W.J., Sinclair, A.J., 1983. Differentiation of meat according to species by the electrophoretic separation of muscle lactate dehydrogenase and esterase isoenzymes and isoelectric focusing of soluble muscle proteins. Australian Veterinary Journal 60, 47-51.

Soares, S., Amaral, J.S., Mafra, I., Oliveira, M.B.P.P., 2010. Quantitative detection of poultry meat adulteration with pork by a duplex PCR assay. Meat Science 85, 531-536.

Soares, S., Amaral, J.S., Oliveira, M.B.P.P., Mafra, I., 2013. A SYBR Green real-time PCR assay to detect and quantify pork meat in processed poultry meat products. Meat Science 94, 115-120.

Stamoulis, P., Stamatis, C., Sarafidou, T., Mamuris, Z., 2010. Development and application of molecular markers for poultry meat identification in food chain. Food Control 21, 1061-1065.

Taylor, S.L., Nordlee, J.A., Niemann, L.M., Lambrecht, D.M., 2009. Allergen immunoassays. Considerations for use of naturally incurred standards. Analytical and Bioanalytical Chemistry 395, 83-92.

Tillmar, A.O., Dell'Amico, B., Welander, J., Holmlund, G., 2013. A universal method for species identification of mammals utilizing next generation sequencing for the analysis of DNA mixtures. PLoS One 8, e83761.

Tisza, Á., Csikós, Á., Simon, Á., Gulyás, G., Jávor, A., Czeglédi, L., 2016. Identification of poultry species using polymerase chain reaction-single strand conformation polymorphism 
(PCR-SSCP) and capillary electrophoresis-single strand conformation polymorphism (CESSCP) methods. Food Control 59, 430-438.

Tobe, S.S., Linacre, A.M.T., 2008. A multiplex assay to identify 18 European mammal species from mixtures using the mitochondrial cytochrome b gene. Electrophoresis 29, 340-347.

Vallejo-Cordoba, B., Cota-Rivas, M., 1998. Meat species identification by linear discriminant analysis of capillary electrophoresis protein profiles. Journal of Capillary Electrophoresis 5, $171-175$.

Vallejo-Cordoba, B., Rodríguez-Ramírez, R., González-Córdova, A.F., 2010. Capillary electrophoresis for bovine and ostrich meat characterisation. Food Chemistry 120, 304-307.

Walker, J.A., Hughes, D.A., Anders, B.A., Shewale, J., Sinha, S.K., Batzer, M.A., 2003. Quantitative intra-short interspersed element PCR species-specific DNA identification. Analytical Biochemistry 316, 259-269.

Wang, W., Chen, K., Xu, C., 2006. DNA quantification using EvaGreen and a real-time PCR instrument. Analytical Biochemistry 356, 303-305.

Wang, W., Zhu, Y., Chen, Y., Xu, X., Zhou, G., 2015. Rapid visual detection of eight meat species using optical thin-film biosensor chips. Journal of AOAC International 98, 410-414.

Wolf, C., Rentsch, J., Hübner, P., 1999. PCR-RFLP Analysis of mitochondrial DNA: a reliable method for species identification. Journal of Agricultural and Food Chemistry 47, 1350-1355.

Wu, Y., Yang, Y., Wang, B., Liu, M., Han, J., Chen, Y., 2015. A real-time PCR method targeting camel ingredient for food authentication. Journal of AOAC International 98, 1640-1644.

Yang, S., Li, C., Wu, Q., Zhu, C., Xu, X., Zhou, G., 2014. High-resolution melting analysis: a promising molecular method for meat traceability. European Food Research and Technology 239, 473-480.

Yusop, M.H.M., Mustafa, S., Man, Y.B.C., Omar, A.R., Mokhtar, N.F.K., 2012. Detection of raw pork targeting porcine-specific mitochondrial cytochrome $\mathrm{b}$ gene by molecular beacon probe real-time polymerase chain reaction. Food Analytical Methods 5, 422-429.

Zha, D., Xing, X., Yang, F., 2010. A multiplex PCR assay for fraud identification of deer products. Food Control 21, 1402-1407.

Zha, D.-M., Xing, X.-M., Yang, F.-H., 2011. Rapid identification of deer products by multiplex PCR assay. Food Chemistry 129, 1904-1908.

Zhang, C., 2013. Semi-nested multiplex PCR enhanced method sensitivity of species detection in further-processed meats. Food Control 31, 326-330.

Zhang, C.L., Fowler, M.R., Scott, N.W., Lawson, G., Slater, A., 2007. A TaqMan real-time PCR system for the identification and quantification of bovine DNA in meats, milks and cheeses. Food Control 18, 1149-1158.

Zvereva, E.A., Kovalev, L.I., Ivanov, A.V., Kovaleva, M.A., Zherdev, A.V., Shishkin, S.S., Lisitsyn, A.B., Chernukha, I.M., Dzantiev, B.B., 2015. Enzyme immunoassay and proteomic characterization of troponin I as a marker of mammalian muscle compounds in raw meat and some meat products. Meat Science 105, 46-52. 
Advances in Food Authenticity Testing covers a topic of great importance to both the food industry, which is obliged to provide clear and accurate labelling of their products as well as maintain food safety, and governments and organizations tasked with verification of claims of food authenticity. The adulteration of foods with cheaper alternatives has a long history, but the analytical techniques which can be implemented to test for adulteration are ever advancing.

This book covers the wide range of methods and techniques utilized in the testing of food authenticity, including new implementations and processes. The first part of the book examines in detail the scientific basis and the process of how these techniques are used. The rest of the book highlights specific examples of the use of these techniques in the testing of various foods.

Written by experts in both academia and industry, the book provides the most upto-date and comprehensive coverage of this important and rapidly progressing field.

\begin{abstract}
About the Editor
Gerard Downey is a member of the Food Chemistry and Technology Department at the Ashtown Food Research Centre of Teagasc, Ireland's Agriculture and Food Development Agency. He also holds the post of Adjunct Full Professor in the School of Agriculture, Food and Veterinary Science at University College Dublin, is a Fellow of the International Union of Pure and Applied Chemistry (IUPAC), and is the holder of the 2006 Tomas Hirschfeld Award for Outstanding Achievements in Near Infrared Spectroscopy. He has been active in the application of vibrational spectroscopy to food authenticity and adulteration studies for more than $\mathbf{3 0}$ years and has participated in many EU-funded projects on this topic.
\end{abstract}

